\title{
LEGAL AND PUBLIC POLICY CONSIDERATIONS THAT JUSTIFY LEGISLATIVE DEVELOPMENT OF THE LAW OF DELICT
}

\section{Bernard Wessels*}

\section{ABSTRACT}

An evaluation of the different ways in which the South African legal system currently provides compensation for crime victims suggests that an alternative form of crime victim compensation should be considered. The most common solution adopted in foreign jurisdictions is the enactment of a statutory crime victim compensation scheme. The crucial question is whether such legislative development could be justified in South Africa. To investigate the justifiability of a crime victim compensation scheme, the following approach is suggested. First, a theoretical framework must be developed to provide an outline for justifiable statutory reform of the law of delict insofar as the compensation of victims is generally concerned. Only once this has been done, can attention be given to the more specific question, namely whether the potential enactment of a statutory compensation fund for crime victims could fit into such a framework. This contribution focuses on the first issue, namely setting out a theoretical framework for future justifiable statutory development of the law of delict. This is done by identifying legal and public policy considerations that the

* Senior lecturer in Private Law, Stellenbosch University. The contribution is based on a chapterin my LLD thesis completed at Stellenbosch University in 2018 with the title Developing the South African Law of Delict: The Creation of a Statutory Compensation Fund for Crime Victims. I would like to acknowledge the financial support that I received from Stellenbosch University (HB \& MJ Thom bursary), which assisted greatly in conducting legal historical research and finalising this contribution 


\section{BERNARD WESSELS}

legislature have used in the past to develop the law relating to the compensation of specific categories of victims. This contribution therefore looks at the historical development of three major statutes that have developed the law relating to the compensation of specific categories of victims: the Road Accident Fund Act 56 of 1996, the Compensation for Occupational Injuries and Diseases Act 130 of 1993 and the Consumer Protection Act 68 of 2008.

Key words: Law of delict; crime victim compensation; statutory development of the law of delict; legal and public policy considerations

\section{Introduction}

The way in which the South African legal system seeks to repair the harm suffered by crime victims has been described and evaluated elsewhere. ${ }^{1}$ In short, it was concluded that there are several theoretical and practical problems associated with crime victim compensation and that it was worthwhile to investigate alternatives. These difficulties may be summarised as follows:

First, it should be emphasised that the likely indigence of South African criminals presents a significant obstacle to securing compensation through the institution of common-law delictual remedies against the perpetrator. ${ }^{2}$ As a result, those who have suffered harm arising from crime have had to adopt a different strategy. ${ }^{3}$ The recent past has seen these victims argue that it is the state, rather than the perpetrator of the crime, that should be held delictually liable for harm arising from crime. ${ }^{4}$ More specifically, they have argued that the state should be held vicariously liable in delict on the basis that its employees culpably and wrongfully caused the victim's harm, either by action or inaction. This strategy has proven to be remarkably successful and has led to the significant expansion of the state's liability for harm arising from crime.

1 See Wessels 2018: 31-127 for a description and evaluation of the current South African legal position regarding the compensation of harm suffered by crime victims. Attention is given to the compensation of harm via common-law remedies in the law of delict, as well as the current statutory response to compensating crime victims.

2 South African Law Reform Commission 2004: 74, 281-282. See, further, Wessels 2018: 15, 116-117, 177-183, 212-214.

3 See Wessels 2018: 37-105 for a detailed description of this strategy, as well as consequential expansion of state delictual liability for harm arising from crime.

4 Indeed, an overview of the South African law reports provide remarkably few examples of instances where a crime victim instituted a delictual claim against the purported criminal to repair the harm he suffered. For example, in the following cases the victim instituted the condictio furtiva for theft of his property: Chetty v Italtile Ceramics Ltd 2013 (3) SA 374 (SCA); Crots v Pretorius 2010 (6) SA 512 (SCA); First National Bank of Southern Africa Ltd v East Coast Design CC 2000 (4) SA 137 (D); Clifford v Farinha 1988 (4) SA 315 (W). In the following cases the victim instituted a claim arising from violent crime: $N v$ T 1994 (1) SA 862 (C); Mabaso v Felix 1981 (3) SA 865 (A); Schoultz v Potgieter 1972 (3) SA 371 (E); Manuel v Holland 1972 (4) SA 454 (R); Wessels v Pretorius, NO 1974 (3) SA 299 (NC); Mbatha v Van Staden 1982 (2) SA 260 (N); Groenewald v Groenewald 1998 (2) SA 1106 (SCA). However, most of the cases dealing with crime victim compensation involves the institution of a civil claim against the state. 
In this context, regard may be had to a report on the extent and impact of civil claims against the South African Police Services (SAPS). The report stated that, in recent years, the SAPS have "reported a substantial annual increase in civil claims filed for damages as a result of actions or omissions by its officials, and an even larger increase in claims pending. The 2014/2015 SAPS annual report showed that pending claims stood at over R26 billion, which is equivalent to over a third of the SAPS budget". ${ }^{5}$ The report alleges that between 2007/08 and 2014/15, "claims made annually against the SAPS increased by 533\% if considering the original rand valued, or $313 \%$ if adjusted to the same rand value". ${ }^{6}$ Lastly, it records that, in a parliamentary reply, the Minister of Police indicated that "just under R570 million had been spent by the SAPS on legal costs relating to civil claims between 2011/12 and 2013/14". ${ }^{7}$

This development presents theoretical and practical difficulties. Most significantly, on a practical level, it imposes a substantial financial burden on the state, which, in turn, threatens its overall ability to provide safety and security services and to prevent crime. This problem may be summarised in the following way: when the state employer is held vicariously liable for the culpable wrongdoing of an employee and is ordered to pay the crime victim's damages, it is the taxpayer who ultimately has to bear the cost. However, if taxpayer money is used to pay compensation, then less money is available for performing the state's ordinary tasks, namely, in the case of the police, preventing crime and promoting safety and security. ${ }^{8}$ Of course, this decreased ability to prevent crime only further serves to increase the likelihood of a higher crime rate and the accompanying litigation that may be instituted against the state on the basis that it failed to prevent crime. This means that the South African law of delict appears to be caught in a vicious circle of ever-expanding state delictual liability for harm arising from crime. ${ }^{9}$

5 Dereymaeker 2015: 29

$6 \quad$ Idem at 31.

$7 \quad$ Idem at 34

8 See, also, Wessels 2019: 8-10 for a discussion of the same problem within the context of harm arising from medical malpractice in the public healthcare sector.

9 The extension of state delictual liability for harm arising from intentionally-committed crimes (through judgements in Kv Minister of Safety and Security 2005 (6) SA 419 (CC), as well as Fv Minister of Safety and Security 2012 (1) SA 536 (CC)) have received particular criticism. Some of the theoretical concerns associated with this recent development include the following: First, it has been argued that future application of the reasoning in these judgements may produce arbitrary outcomes. This may produce legal uncertainty and lead to arbitrary conclusions being reached in similar cases. Secondly, these judgements interpreted each of the individual policemen's actions involved in the crimes as simultaneously constituting both a positive, intentional delict, as well as a wrongful and negligent failure to comply with their legal duties to protect the victim from crime. This has apparently been done in an attempt to establish a sufficiently close connection between their employment and their wrongdoing for the sake of finding vicarious liability. However, this reasoning is not aligned with practical reality and may also lead to untenable outcomes from an employer's perspective. Also, the Constitutional Court's appeal to the constitutional rights referred to in these cases ultimately cannot assist a court in determining whether certain conduct occurred within the course and scope of employment. It may further be argued that the court's 


\section{BERNARD WESSELS}

Furthermore, it has been pointed out that crime victims who want to institute common-law delictual claims directly against the state may likely face significant evidentiary difficulties in proving systemic negligence. ${ }^{10}$ This is particularly the case where the crime victim seeks to hold the state directly (as opposed to vicariously) liable. In addition, the assistance provided by the Criminal Procedure Act 51 of 1977 and the Prevention of Organised Crime Act 121 of 1998 in relation to crime victim compensation is unsatisfactory. ${ }^{11}$

Against that background, it was proposed that an alternative method should be investigated to provide compensation for crime victims. One particular alternative that has been adopted in various foreign jurisdictions is the establishment of a statutory compensation fund for crime victims. ${ }^{12}$ This would potentially amount to the statutory development of the law of delict, at least insofar as the compensation of crime victims is concerned. This presents a particular dilemma because, in this context, scholars, such as Atiyah and Cane, have raised their concern over the lack of a justifiable basis for this type of legislative intervention: "[T] he idea of selecting this group of injured and disabled people for special treatment is not easily defensible." 13 Indeed, academics have consequently emphasised a "fundamental problem" 14 that confronts reformers of the law of delict/tort law in this context, which is that "it is

reliance on the role that trust played in establishing vicarious liability in these (and future) cases may be questioned on the basis that it allows for different outcomes being reached on similar facts. Lastly, the application of the vicarious liability doctrine in these cases undermine the balance that has traditionally been sought to achieve between the interests of the employer, employee and victim. Instead, the primary focus is on the compensation of the victim's harm. However, if this is the case, it may be worthwhile to investigate alternative methods that may very well be more effective in achieving that goal. For a detailed discussion of these and related matters, see, further, Wessels 2018: 36-115.

10 See Wessels 2018: 105-112, 171-177 for a critical discussion of two cases (Shabalala v Metrorail 2008 (3) SA 142 (SCA) and Mashongwa v Passenger Rail Agency of South Africa 2016 (3) SA $528(\mathrm{CC}))$ in particular that illustrate this point.

11 For a detailed analysis of all of the aspects of these statutes that have a bearing on the issue of crime victim compensation, see, generally, Wessels 2018: 112-123.

12 New Zealand was the first jurisdiction to adopt a crime victim compensation scheme in 1963 , shortly followed by the United Kingdom (UK), where such a scheme became operative in 1964. Thereafter, this solution was also endorsed in several European jurisdictions, as well as in various Australian, American and Canadian states and territories. A detailed description of the historical development leading to the enactment of these schemes and a discussion of the operation of the schemes in the respective jurisdictions fall outside the scope of this contribution. However, for a comprehensive discussion of these issues, see, in general, Scott 1967; Cameron 1963; Fry 1959; Goodey 2003; Greer 1996; McGillis \& Smith 1983; National Center for Victims of Crime 2004; Canadian Resource Center for Victims of Crime sd; Miers 2014; and Wessels 2018: 226-237, $243-$ 318 for a critical analysis of some of the existing policies and programmes that have a bearing on the position of crime victims in South Africa and for a detailed comparison between the crime victim compensation schemes in the UK and the Netherlands (including a discussion of the practical considerations that may have to be taken into account, should the South African legislature decide to enact such a scheme).

13 Cane 2013: 303-308.

14 SALRC 2004: 182-183. See, also, Scott 1967: 281; Cane 2013: 303-308. 
difficult to find a satisfactory rationale for singling out violent-crime victims from other groups of unfortunates for special treatment by the state". ${ }^{15}$

The problem with justifying statutory development through the enactment of a crime victim compensation fund has also been highlighted in South Africa. It may be recalled that the South African Law Reform Commission (SALRC) examined this potential alternative and published a report on their findings in 2004 (SALRC Report),${ }^{16}$ while a doctoral dissertation ${ }^{17}$ also examined the establishment of a compensation fund. However, neither of these research projects dealt with the issue of justification. ${ }^{18}$

Justifying the potential enactment of a statutory crime victim compensation fund is important for a number of reasons. Obviously, as the SALRC itself pointed out, "developing a motivation for the establishment of a [statutory compensation fund] in SA remains incomplete, and must be completed if legislation is to be drafted, since no law should be passed without its objectives being clearly defined and costed". ${ }^{19}$ Indeed, intervention of this kind, which necessarily requires taxpayer funding, would require a justifiable policy basis to explain why preferential treatment is being offered to crime victims as a specific category. Also, one would need a basis of this kind to inform the purpose, scope and extent of the statute, if it were to be enacted. A clear policy framework would further assist in guiding interpretation of particular provisions of the potential act. Without such a basis, the statute may present potential crime victims, administrators and courts with an undesirable level of uncertainty.

To investigate the justifiability of a crime victim compensation fund, the following approach will be adopted. This contribution will advance a theoretical framework that provides an outline for justifiable statutory reform of the law of delict insofar as the compensation of victims is generally concerned. This will be done by identifying legal and public policy considerations that the legislature have

15 SALRC 2004: 182.

16 Idem passim.

17 See Von Bonde 2007.

18 The SALRC's report provides a summary of the violent crime situation in South Africa and of the impact of crime on South Africa; outlines the South African legal system's compensatory regime, provides a comparative overview of the compensation funds for violent crime victims established in some foreign jurisdictions and deals briefly with the advantages and disadvantages of establishing a compensation fund for crime victims in South Africa; examines the role of the criminal justice system in addressing the harm done to the victim of crime. However, it does not set out the legal and public policy considerations that may justify the legislative development of the law of delict. Similarly, Von Bonde's thesis focuses on the rationale underlying the restitution of crime victims; sets out the historical development of the compensation fund for crime victims in foreign jurisdictions; provides a comparative overview of the compensation funds that have been established in foreign jurisdictions (including England, India and New Zealand); and examines the role of the criminal justice system (both in South Africa and abroad) in providing compensation to crime victims. However, it does not provide a justificatory framework for the statutory intervention in the law of delict.

19 SALRC 2004: 318-319. 


\section{BERNARD WESSELS}

used in the past to develop the law relating to the compensation of specific categories of victims. Only once this has been done, can attention be given to the more specific question, namely whether the potential enactment of a statutory compensation fund for crime victims could fit into such a framework..$^{20}$

In surveying the historical development of specific South African statutes that have had a major impact on the common law of delict, attention will specifically be paid to the following statutes: the Compensation for Occupational Injuries and Diseases Act 130 of 1993 (COIDA), the Road Accident Fund Act 56 of 1996 (RAF Act), as amended by the Road Accident Fund Amendment Act 15 of 2005 (RAFA Act) and the Consumer Protection Act 68 of 2008 (CPA). Although there are several other statutes that have had a notable influence on the law of delict, ${ }^{21}$ the focus will be on these statutes because they predominantly deal with the compensation of a specific group of victims of harm: motor vehicle accident victims, victims of defective consumer products and those who suffer harm as a result of occupational injuries and diseases. In some way or another, all of these statutes have singled out a collection of individuals for preferential treatment while aligning themselves with the primary function of the law of delict, namely the compensation of harm. ${ }^{22} \mathrm{In}$ addition, COIDA and the RAF Act have also established statutory compensation funds. Considering that the aim here is to investigate the feasibility of establishing a fund designed to compensate a different group of victims, it is appropriate to examine the legal and public policy considerations that have justified the enactment of these specific statutes.

The considerations that are discussed in greater detail include the following: First, the need to combat the risk of harm, the role of the Constitution of the Republic of South Africa, 1996 (Constitution) and the need to promote the constitutional right to social security, as well as evidentiary problems relating to the application of the common-law fault requirement will be given attention. Thereafter, an analysis follows of the general dissatisfaction with the high transaction costs and levels of under-compensation characteristic of the civil procedural system, the preference for statutory as opposed to judicial reform and the need to avoid arbitrary outcomes. In conducting this investigation, use is at times made of legal comparative methodology, which has proven to be an instructive tool to understand domestic law and to evaluate it in the light of the experiences of other jurisdictions.

20 This question has been dealt with in Wessels 2018: 189-239, where the author deals with the policy considerations in the specific context of crime victim compensation, and will form the basis for a separate article.

21 For example, the Apportionment of Damages Act 34 of 1956, which was described as being the "most important piece of law reform that has been carried out in the field of private law since Union". See McKerron 1956: 1.

22 For overviews of the function of the law of delict, see Macintosh 1926: 1; Van den Heever 1944: 3; McKerron 1971: passim; Van der Merwe \& Olivier 1976: 1-3; Neethling \& Potgieter 2015: 3-17; Van der Walt \& Midgley 2016: passim; Loubser \& Midgley 2017: 9-15. These authors are in agreement insofar as compensation is regarded as being the primary function of this branch of the law. 
Lastly, it may be added that a similar problem regarding justification has also been identified in the context of the state's expanding liability for harm arising from medical malpractice in the public healthcare sector. ${ }^{23}$ As a response to this development, the state has tabled the State Liability Amendment Bill of 2018, which, essentially, proposes the introduction of structured settlements and the making of periodic payments to certain victims of medical malpractice. When commenting on the Bill in its parliamentary submission, the South African Law Society argued that "[s]ingling out victims of wrongful medical treatment at the hands of the State for 'structured payments' and denying lump sums for future losses and expenses is clearly discriminatory [and] impermissibly differentiates between victims of medical wrongdoing and other victims injured by the State and in so doing it limits the right to equal protection and benefit of the law guaranteed by Section 9(1)". ${ }^{24}$ Therefore, the theoretical framework that this contribution seeks to establish may also be used to guide subsequent deliberation on whether the potential legislative development of the law of delict relating to medical malpractice compensation may be justified.

\section{Legal and public policy considerations that have justified the statutory reform of the South African law of delict}

\section{The need to combat the risk of harm}

Generally, the existence and extent of a risk of harm has played an important role in the South African legislature's decision to develop the law of delict. ${ }^{25}$ This has especially been the case in the context of motor vehicle accidents, occupational injuries and diseases, and defective consumer products.

\section{Motor vehicle accidents}

The introduction of the motor vehicle towards the end of the nineteenth century had profound consequences of a technical, social, financial and legal nature. ${ }^{26}$ One of the effects that accompanied its introduction to the marketplace was the increased risk of harm to especially bodily integrity and property. Arguably, this characteristic

23 For an overview of the expansion of state delictual liability within that context, see, generally, SALRC 2017; Wessels 2019: 1-23.

24 Law Society of South Africa 2018:8.

25 See Loubser 1993: 3; Van der Nest 2003: 501-516; Olivier 2007a: pars 158-159; Loubser \& Reid 2012: 4-5. For a comparative perspective, see, also, Cane 2013: 326-357, 459-487; Stapleton 1994: 6; Deakin, Johnston \& Markesinis 2013: 51-60, 599-604; Markesinis \& Unberath 2002: 714-717, 724-729.

26 Cooper 1996: 1. 


\title{
BERNARD WESSELS
}

of motor vehicles provided the dominant reason for legislative reform within this context. ${ }^{27}$ Writing about the general impact that motor vehicles have had on the law of delict, Cooper states: ${ }^{28}$

\begin{abstract}
A motor car is a potentially dangerous machine. Its technical improvement, with the attendant increase in speed, and the increase in the volume of vehicular road traffic, with the inevitable increase in the number of accidents (which can be described as the materialization of the risk inherent in the operation of the motor car), have confronted the courts with a variety of delictual problems requiring judicial determination. In the process the motor car has become the single most potent instrument for the development and reform of the law of delict in the twentieth century.
\end{abstract}

More specifically, the rise of motor vehicles produced an increase of two types of risk. First, the rise in motor vehicle traffic has brought about a significant increase in risk to the bodily integrity and property of drivers, passengers and pedestrians. ${ }^{29}$ This is substantiated by the available data in respect of the use of motor vehicles in South Africa.$^{30}$ Further, when this risk of injury materialises as the result of the culpable conduct of another, the victim may institute a delictual claim against the wrongdoer in search of compensation of his harm. ${ }^{31}$ Wrongdoers, however, are often unable to pay any or all of the damages required to repair the victim's harm. ${ }^{32}$ In Law Society of South Africa v Minister for Transport, ${ }^{33}$ Moseneke DCJ remarked that, "[in his] view, the number of drivers and owners who would be able to pay would be very small" ${ }^{34}$ In turn, this inability may expose a wrongdoer's victim to the further risk of receiving limited or no compensation in respect of the harm they suffered ${ }^{35} \mathrm{Nugent}$ JA referred to the impact that risk has in this context as follows: ${ }^{36}$

People need cars, cars knock people over, people are injured, we cannot bear the cost of knocking people over. It is inherently risky for those who knock people over and for those

27 Idem at $2-3$

28 Idem at 2.

29 Loubser 1993: 3; Van der Nest 2003: 501-516; Olivier 2007a: pars 158-159.

30 For an overview of all of the relevant data, see, generally, Wessels 2018: 136. For present purposes it would suffice to note that along with the rise in the number of motor vehicles between 1935 and 2000 (284 216 to 6814531 ), there has been a significant rise in the amount of people injured as a result of motor vehicle accidents (13532 to 159 704).

31 Law Society of South Africa v Minister for Transport and Another 2011 (1) SA 400 (CC) par 50. Recent amendments to the RAF Act have, however, abolished the motor vehicle accident victim's common-law claim against wrongdoers. See, further, Wessels 2018: 291-295.

32 Workmen's Compensation Commissioner v Norwich Union Fire Insurance Society Ltd 1953 (2) SA 546 (AD) at 551; Loubser 1993: 3; Van der Nest 2003: 502; Olivier 2007a: pars 58-159; Olivier 2007b: pars 10-21.

332011 (1) SA 400 (CC).

34 Idem par 50.

35 Loubser 1993: 3; Van der Nest 2003: 502; Olivier 2007a: pars 158-159.

36 Road Accident Fund Commission 2002: 103. 
who are knocked over. The two problems are: People who are driving cannot afford the risk of knocking people over and the people who are using the roads cannot afford the risk of being knocked over.

To protect road users from the potential realisation of these risks and to ensure the compensation of motor vehicle accident victims, the South African legislature decided to intervene in the law of delict by enacting motor vehicle accident legislation. To a certain extent, the legislation that was introduced in this context was based on similar statutes enacted by the English legislature during the course of the 1930s. ${ }^{37}$ It might therefore be worthwhile to reflect on the policy reasons that influenced the English legislature in this regard.

During the first part of the nineteenth century, under traditional " "horse and buggy law' ... the driver or rider was only liable in so far as he was at fault". ${ }^{38}$ Following the judgement in Rylands $v$ Fletcher, ${ }^{39}$ however, the theory of strict liability emerged, as a result of which it was held that damages could be payable when injury was inflicted in the course of conducting a business for profit, even if there was no question of fault. ${ }^{40}$ It was argued that, if a car damaged people or property, the person who brought the car onto the highway should be held strictly liable. ${ }^{41}$ This development, however, came to a halt in Wing $v$ London General Omnibus Company ${ }^{42}$ when the Court of Appeal dismissed the notion that motor cars were, generally speaking, inherently dangerous things. The effect of this judgement was that the law of torts relating to motor vehicle accidents in the early twentieth century was made to rest "squarely upon the basis of fault liability upon which it has rested ever since". ${ }^{43}$

Although the number of motor vehicle accidents in the UK was initially small and ownership of vehicles was restricted to a limited, wealthy class, they gradually became cheaper, which meant that ownership became more widespread. ${ }^{44}$ The significant rise in motor vehicles in the UK resulted in a substantial surge in the number of motor vehicle accidents. ${ }^{45}$ The fact that the appeal for reform of the branch of law dealing with the compensation of harm caused by motor vehicle accidents reached a highpoint during this period is therefore unsurprising. ${ }^{46}$ Bartrip describes the increased use of motor vehicles and its accompanying risk of harm as follows: ${ }^{47}$

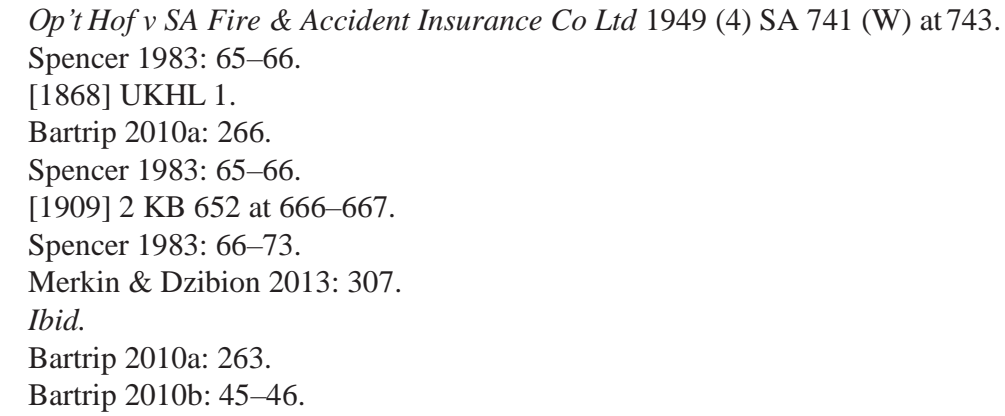


Whatever the perceived or alleged benefits of motorised transport, it cannot be doubted that motor vehicles took a tremendous toll of human life and limb in twentieth-century Britain. Official records for the years 1930 to 1939 (inclusive) indicate that 69824 people died on Britain's roads, at an average rate of just over 7000 per year. Between 1920, when records began, and 1930 the annual number of road deaths rose at a staggering rate from 4886 to 7305 .

To address the issue of motor vehicle accidents and related matters, a Royal Commission was appointed in 1928. On the basis of its recommendations, a Bill was proposed and ultimately passed by the English legislature as the Road Traffic Act of 1930. Significantly, the Act introduced a system of third-party compulsory insurance, making it unlawful to use a motor vehicle unless an insurance policy in respect of "third party risks" was in force..$^{48}$ This system of compulsory third-party insurance has been maintained under the Road Traffic Act of 1988. ${ }^{49}$

Similar to England, South Africa experienced a dramatic increase in the use of motor vehicles during the course of the 1930s, which brought with it an increase in motor vehicle accidents. ${ }^{50}$ Analogous to the situation in England, this led to considerable pressure on the South African legislature to alleviate the plight of road accident victims. ${ }^{51}$ The need was expressed to protect motor vehicle accident victims against the possibility of limited or no recovery of harm, because the wrongdoer "was a 'man of straw' and unable to pay the road accident victim's loss or damage". ${ }^{2}$ Accordingly, the South African legislature followed the lead of the English legislature in 1939 when it decided to introduce the first Bill aimed at protecting motor vehicle accident victims. During a debate of the Bill, the Minister of Finance referred to the legal and public policy considerations underlying justifiable legislative reform of the law of delict within this context: ${ }^{53}$

I am of the view that this Bill may be described as one which is designed to meet a long-felt want. Its object is to ensure the payment of compensation for injuries or death caused by negligence in the use of motor transport. I think honorable members are aware that there are a considerable number of motor vehicles in the Union driven by people who are not insured against what are known as third party risks. I think I shall probably be correct in saying that that is the case with the majority of the motor vehicles in the Union, and that, of course,

48 Deak 1936: 566.

49 See s 143 of the Road Traffic Act (c 52) of 1988.

50 See, also, the second reading of the draft Motor Vehicle Insurance Act 29 of 1942 in Parliament, where the Minister of Finance refers to this consideration as legal and public policy consideration justifying the Act: Debatte van die Volksraad Deel 43 1942: 1255-1259. For an overview of all the relevant data, see the table in Wessels 2018: 136. To illustrate the above point, however, it would suffice to note that along with the rise in motor vehicles between 1935 and 2000 (284 216 to 6814531 ), there has been a significant rise in the amount of people injured as a result of motor vehicle accidents (13 532 to 159704$)$.

51 Road Accident Fund Commission (RAFC) 2002: 108-112.

52 Idem at 108

53 Debatte van die Volksraad Deel 43 1942: 1255-1259 (own translation). 


\section{LEGAL AND PUBLIC POLICY CONSIDERATIONS}

means that when harm is brought about through the negligence of an uninsured motorist and he is unable to meet a claim for compensation, the innocent victim is left without any redress.

The Motor Vehicle Insurance Act 29 of 1942 ultimately came into effect in 1946. Its aim, as stated in its preamble, was to "provide for compensation for certain loss or damage caused unlawfully by means of motor vehicles and for matters incidental thereto". The Act introduced compulsory third-party insurance on a national scale and compelled the owners of motor vehicles, generally, to take out insurance so that motor vehicle accident victims may be properly compensated for the harm they suffered arising from the negligent and unlawful driving of a motor vehicle. ${ }^{54}$

In Rose's Car Hire (Pty) Ltd v Grant ${ }^{55}$ the Appellate Division confirmed that the intention behind the legislature's decision was to ensure, through the compulsory insurance of motor vehicles, that injured persons or their dependants who might not be able to recover damages owing to the inability of the parties liable to pay, should receive full compensation from insurers in as many cases as possible. Shortly thereafter, in Aetna Insurance Co v Minister of Justice, the same court reaffirmed the purpose of the legislative intervention as follows: ${ }^{56}$

\footnotetext{
The obvious evil that [the Act] is designed to remedy is that members of the public who are injured, and the dependants of those who are killed, through the negligent driving of motor vehicles may find themselves without redress against the wrongdoer. If the driver of the motor vehicle or his master is without means and is uninsured, the person who has been injured or his dependants, if he has been killed, are in fact remediless and are compelled to bear the loss themselves. To remedy that evil, the Act provides a system of compul- sory insurance.
}

The 1942 Act underwent regular amendments and was replaced by the Compulsory Motor Vehicle Insurance Act 56 of 1972, which came into operation in 1972. The motivation behind the enactment of new legislation was not to pursue a purpose different to that outlined above, but rather to amend the mechanics by means of which the aim was sought to be achieved. ${ }^{57}$ As is evident from a series of cases dealing with liability under the 1972 Act, ${ }^{58}$ the legislature's primary focus was still

54 Klopper 2000: 3; Cooper 1996: 3. See, also, RAFC 2002: 110: The insurance would cover harm as a result of bodily injuries or death of a breadwinner arising from the culpable and unlawful driving of a motor vehicle, but did not cover property damage or other harm that may have been suffered as a result of the accident.

$551948(2)$ SA $466($ A) at 471.

561960 (3) SA 273 (A) at 285.

57 The Act required the insurance of the vehicle and not insurance of the owner or driver. It also provided cover (through the newly established Motor Vehicle Assurance Fund), for the first time, for loss occasioned by uninsured or unidentified motor vehicles. See, further, Law Society of South Africa v Minister for Transport 2011 (1) SA 400 (CC) par 20.

58 See Commercial Union Assurance Company of South Africa Ltd v Clarke 1972 (3) SA 508 (AD) at 518; AA Mutual Insurance Association Ltd v Biddulph 1976 (1) SA 725 (AD) at 738; Webster $v$ Santam Insurance Co Ltd 1977 (2) SA 874 (AD) at 881; Nkisimane v Santam Insurance Co Ltd 1978 (2) SA $430(\mathrm{AD})$ at 435. 


\section{BERNARD WESSELS}

the protection of those who suffer harm ${ }^{59}$ as a result of motor vehicle accidents and who might be unable to recover damages owing to the wrongdoer's inability to pay compensation. ${ }^{60}$ Similar to its predecessor, the Act was based on the common-law principles of delictual liability, which required an accident victim to prove that his harm had been caused by the culpable and unlawful driving of a motor vehicle.

The 1972 Act was substituted by the Motor Vehicle Accident Act 84 of 1986 (MVA Act). The MVAAct, which came into operation in 1986, introduced a number of changes ${ }^{61}$ Importantly, it replaced the former system of compulsory third-party insurance with a system of statutory assumption of liability in respect of harm suffered by road users as a result of the negligent and unlawful driving of a motor vehicle. ${ }^{62}$ To achieve this, the legislature established the Motor Vehicle Accident Fund (MVA Fund), financed by fuel levies, to fund the new statutory system of compensation of harm. Because the MVA Act was effective only in South Africa and Namibia, but not in the former so-called independent territories of Transkei, Bophuthatswana, Venda and Ciskei, the Multilateral Motor Vehicle Accidents Fund Act 93 of 1989 (MMF Act) was enacted in 1986 with the view to bringing about a uniform system of thirdparty compensation. ${ }^{63}$ The MMF Act remained applicable up to 1997 , when the newly enacted RAF Act came into operation.

The RAF Act essentially has the same object as that of its predecessors, namely the "payment of compensation for loss or damage wrongfully caused by the driving of motor vehicles". ${ }^{64}$ It was based on the common-law elements for delictual liability and has retained fault as the basis for liability. Although it has been argued that the effect of the Act was to "suspend the common law delictual action against the wrongdoer and to compel the road accident victim to institute his claim against the Road Accident Fund", ${ }^{65}$ the delictual claim of the victim was left intact and victims therefore had the option of instituting a claim against the wrongdoer in respect of harm that was not covered under the RAF Act.

59 As was the case with its predecessor, the insurance policies taken out as a result of the Act would cover only harm arising from bodily injuries or the death or bodily injuries of a breadwinner.

60 The preamble of the Act reads as follows: "To provide for the compulsory insurance of certain motor vehicles in order to ensure the payment of compensation for certain loss or damage unlawfully caused by the driving of such motor vehicles; for the payment of compensation where the loss or damage is caused by the driving of an uninsured or unidentified motor vehicle; and for incidental matters." See, also, Suzman, Gordes \& Hodes 1982: 4-6.

61 Law Society of South Africa v Minister for Transport 2011 (1) SA 400 (CC) par 21; Klopper 2000: 4.

62 Klopper 2000: 4.

63 Ibid.

64 Section 3 of the RAF Act. See, also, RAFC 2002: 111-112: Not all damage caused by the unlawful and negligent driving of a motor vehicle can be recovered from the RAF. See Wessels 2018: $307-$ 309 for a discussion of the limitation and exclusion of liability under the RAF Act.

65 RAFC 2002: 111. 
In its 2002 report, the Road Accident Fund Commission (RAFC) described the fault-based compensation system established under the RAF Act as "unreasonable, inequitable, unaffordable and unsustainable" ${ }^{66}$ Among other things, the RAFC found that the Act's insistence on fault-based liability contributed to its financial decline. The criticism of the RAF Act's fault-based liability regime is discussed in further detail in part 2.3 below.

The victim's common-law right to claim compensation from a wrongdoer for harm that is not compensable under the RAF Act was abolished by section 9 of the RAFA Act, which came into force on 1 August 2008. In Law Society of South Africa $v$ Minister for Transport,${ }^{67}$ the Constitutional Court was requested to consider the constitutional validity of this amendment. ${ }^{68}$

In its judgement, the Constitutional Court referred also to the dominant consideration that triggered the amendment - the need to compensate victims of harm that manifests when the risk created by motor vehicles materialises - as well as future reform of the system. In this context, reference was made to the legislature's intention to ultimately replace the common-law system of compensation with a set of limited no-fault benefits that would form part of a broader social security net as public financial support for people who are poor, have a disability or are vulnerable. ${ }^{69}$

The amendments introduced by the RAFA Act provide further evidence of the primary consideration that underlies the enactment of motor vehicle accident legislation in South Africa, namely that it aims to provide compensation where the risk of harm associated with motor vehicle accidents materialises. As explained by the Minister of Transport, although the economic viability of the RAF is an important goal, the ultimate vision is that a new system of compensation for motor vehicle accident victims must be established and integrated into a comprehensive social security system that offers life, disability and health insurance cover for all accidents and diseases. ${ }^{70}$ To achieve the desired reform, the legislature therefore drafted the Road Accident Benefit Scheme Bill (RABS) in 2014. Should it be enacted, the current fault-based system of liability administered by the RAF will be replaced by a new social security scheme for road accidents.

The need to further the constitutional right to social security as a consideration justifying legislative intervention in the law of delict is analysed in part 2.2 below. For the purpose of this part of the contribution, it is sufficient to note here that the proposed RABS is aimed not only at continuing the achievement of the primary aim outlined by its predecessors, namely the protection of the victim's interests by

66 Department of Transport 2011:13.

672011 (1) SA 400 (CC).

68 Idem par 15. A detailed discussion of that judgement falls outside the scope and focus of this contribution. However, in this regard, see Wessels 2018: 291-297.

692011 (1) SA 400 (CC) pars 44-45.

70 Ibid. 


\section{BERNARD WESSELS}

ensuring that he is properly compensated, but also at the promotion of the wrongdoer's interest insofar as the victim's common-law right to claim damages for residual harm has been abolished. In doing so, it may be argued that the legislature seeks to address not only the risk of no compensation to which road users are generally exposed, but also the risk of liability to which culpable road users may be exposed. ${ }^{71}$

It appears that motor vehicle accident legislation may be regarded as "social legislation" 72 aimed at the "widest possible protection and compensation" 73 of road users by compensating them against harm that arises from the culpable and unlawful driving of a motor vehicle.

The RAF Act, its predecessors and its proposed successor provides for the substitution of a compensation fund or an insurance company in the place of a culpable wrongdoer to ensure compensation for a motor vehicle accident victim or his family. ${ }^{74}$ These legislative developments resulted in a conceptual shift from protection of the wrongdoer to acceptance of the need to provide protection and support for all victims of road accidents. ${ }^{75}$

The replacement of the wrongdoer by the RAF undermines the notion that the victim's harm should be compensated - or corrected - by the person who culpably and wrongfully caused it. The fund's existence is therefore arguably not aligned with the so-called corrective justice account for the South African law of delict. ${ }^{76}$

Proponents of the corrective justice account highlight the fact that, properly understood, there must be correlativity between the person who has the duty to rectify the wrong and the person who has suffered the wrong. The corrective justice account of the law of delict may be contrasted with a distributive justice- based justification for this branch of the law. Whereas the latter is concerned with the allocation of resources throughout society as a whole and the criteria on which such an allocation occurs, the basic idea with the former is to do justice between two parties, namely, it is concerned with whether there should be any allocation and if so, to what extent and in what form and on what basis from one person back to another. In other words, from a corrective justice point of view, the law of delict is concerned with justice as between the plaintiff and wrongdoer. Likewise, it is not -

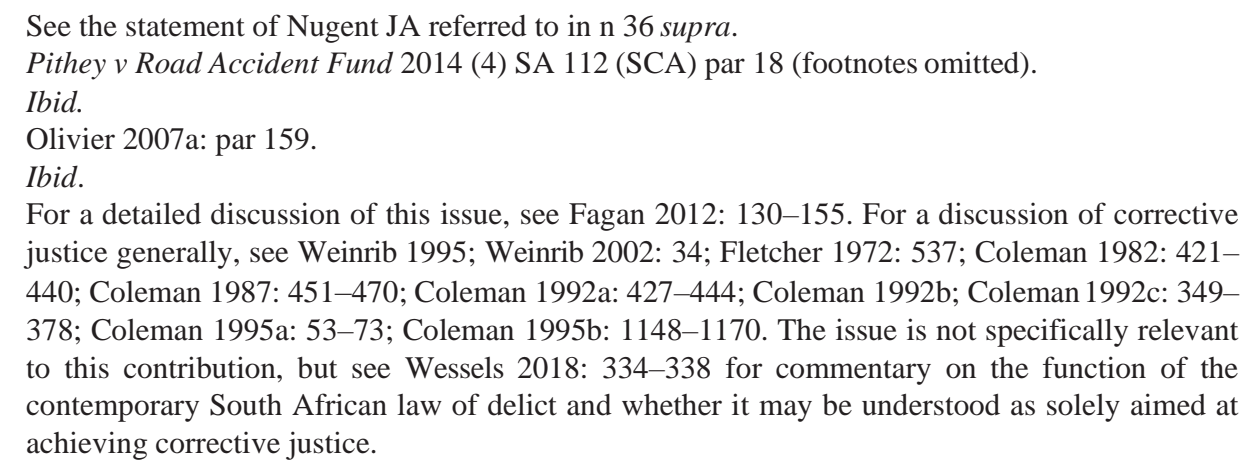
justice generally, see Weinrib 1995; Weinrib 2002: 34; Fletcher 1972: 537; Coleman 1982: 421 440; Coleman 1987: 451-470; Coleman 1992a: 427-444; Coleman 1992b; Coleman 1992c: 349_ 378; Coleman 1995a: 53-73; Coleman 1995b: 1148-1170. The issue is not specifically relevant to this contribution, but see Wessels 2018: 334-338 for commentary on the function of the contemporary South African law of delict and whether it may be understood as solely aimed at achieving corrective justice. 
and should not - be concerned with a global economic picture. Rather, the principles of bipolarity, correlativity and equality should obtain.

Nonetheless, the RAF may be said to fulfil the primary function of the law of delict (compensation of harm), remains based on delictual principles for the time being and is regarded by academics as constituting a part of the South African law of delict. ${ }^{77}$

Lastly, it may be said that, although the legislative intervention did not result in the decrease of the risk of harm arising from the use of motor vehicles, namely in securing general road safety or deterring future motor vehicle accidents, or in deterring future motor vehicle accidents, it was successful insofar as addressing the risk of litigating "against drivers who often were not in a financial position to compensate accident victims for their losses". ${ }^{78}$

\section{Occupational injuries and diseases}

The exposure to risk of harm and associated risk of no compensation has also served as significant motivation for the enactment of legislation aimed at compensating employees who are injured or become diseased during the course and scope of their employment. ${ }^{79}$ Generally, legislative intervention within this context may be justified on the basis that employers often expose their employees to risks specifically associated with their activities as employees, such as to suffer an accident at work or to sustain an illness that is related to a specific health risk of the task assigned to the employee. ${ }^{80}$

Apart from exposing their employees to specific risks associated with their employment activities, an employer exposes the employee to the additional risk of no compensation in the event that the risk of harm materialises. Of course, the exposure to these risks occurs while the employer stands to benefit financially from the efforts of his employee.

Prior to legislative intervention, the position of South African employees who were injured at the workplace was similar to that of motor vehicle accident victims in the pre-legislation era in that they had to institute a common-law delictual claim against their employer to obtain compensation for the harm they had suffered.$^{81} \mathrm{In}$ doing so, they were required to prove that, amongst other things, their employer was at fault, which typically meant that they had to prove their employer's negligence.

77 For example, a discussion of the salient provisions of the RAF is included in Loubser \& Midgley 2017: 556-564.

78 Department of Transport 2011: 6.

79 See Jooste v Supermarket Trading (Pty) Ltd 1999 (2) SA 1 (CC) at 1; Markesinis \& Unberath 2002: 728-230; Deakin, Johnston \& Markesinis 2013: 253-257.

80 Markesinis \& Unberath 2002: 728.

81 Workmen's Compensation Commissioner v Norwich Union Fire Insurance Society Ltd 1953 (2) SA $546(\mathrm{AD})$ at 551. 


\section{BERNARD WESSELS}

As was the case with motor vehicle accident legislation, the South African statutes that were enacted to develop the law of delict in this context were based on similar English statutes enacted during the course of the late nineteenth and early twentieth centuries. ${ }^{82}$

Despite it being possible for employees in nineteenth-century England to institute tort claims against their employers for personal injuries suffered in the workplace as a result of their employers' negligence, employees generally did not do so. ${ }^{83}$ This may be as a result of a variety of legal considerations, including the difficulty in proving fault in the form of negligence, ${ }^{84}$ and the existence of "several draconian defences", ${ }^{85}$ such as the doctrine of common employment, contributory negligence and volenti non fit iniuria, which, to a large extent, enabled employers to evade tortious liability for harm caused to an employee during the course and scope of employment. ${ }^{86}$ Additional social, political and economic considerations that made it problematic for English employees to institute tort claims against their employers have been described as follows: ${ }^{87}$

\footnotetext{
$[\mathrm{M}]$ any workers never thought of suing because they were not even aware that a wrong had been done to them. An accident was an everyday occurrence and part of their way of life, and the risk of injury was seen as in the hands of Fate rather than the employer. If workers were aware that a wrong had been done, they were often ignorant of the possibility of bringing a claim. Those who knew of the tort system found it very difficult to get legal advice. If they did sue, they faced the prospect of incurring legal costs. A more significant deterrent was the likelihood that a tort claim would lead to the loss of work-related benefits such as employer's sick pay, or continued employment in an easier job, or medical treatment from work doctors. Suing an employer often meant antagonising the most powerful men in the region and jeopardizing not only one's employment prospects, but also one's housing, church membership and even access to town poor relief. Nor could workers easily endure the lengthy, complicated and uncertain litigation process itself. Their claims then were opposed by the best lawyers and by morally questionable defence strategies. The final difficulty faced by the workers was that they often needed what tort could not supply: urgent recompense to replace their wage loss.
}

Other policy considerations that influenced the English legislature to interfere with the status quo and to develop the law relating to harm suffered by employees in the course and scope of their employment, may be summarised as follows: the demand for workplace safety, the continuing pressure exerted by trade unions and industrial disputes, the courts' reaffirmation of workers' entitlement to a high

82 Victoria Falls Power Co Ltd v Lloyd NO 1908 TS 1164 at 1165, 1182; Select Committee of the House of Assembly 1904: 15, 17-18.

83 Stein 2008: 935 submits that, in England, the first reported decision of an employer being sued in tort by his employee for a personal injury suffered at the workplace may be traced to 1837 .

84 See part 2.3 infra.

85 Lewis 2012: 138.

86 Deakin, Johnston \& Markesinis 2013: 541-545; Deakin 2013: 253-257.

87 Lewis 2012: 139. 
degree of protection, the steady growth of litigation concerning workplace accidents that became an accepted part of the employment system and the fact that liability insurance became readily available for employers after $1880 .{ }^{88}$ In addition, the industrial revolution in nineteenth-century England caused a significant increase in industrial accidents in the form of, among others, railroad crashes, coalmine explosions and steamboat fires. ${ }^{89}$

The English legislature responded by enacting the Workmen's Compensation Act in 1897. It thereby introduced a no-fault based compensatory system outside tort. ${ }^{90}$ The 1897 Act imposed a statutory duty on employers to make limited payments to the victims of industrial accidents, irrespective of whether those injuries resulted from the culpable wrongdoing of the employer - as long as the accidents arose out of and in the course of employment. ${ }^{91}$ The decision to hold the employer liable regardless of whether or not they acted culpably may be explained with referenceto the concept of enterprise risk or enterprise liability.$^{92}$ In this regard, Deakin writes: ${ }^{93}$

\begin{abstract}
The employer as "enterprise" has a duty of care to have regard for the safety and welfare of its employees and incurs liability to third parties injured by the negligence of those employees not simply because it has "deep pockets" or because of a supposed symmetry between risks and profits, but because its organisational capacity enables it to manage the risks of injury internally, through the bureaucratic structures of the firm, while its financial resources and position in the market make it possible for it to absorb and channel potential liabilities through insurance. Insurance ... makes it possible for firms to shift certain losses, but also sets implicit standards of care, which operate through the monitoring activities, undertaken by liability insurers.
\end{abstract}

The first local legislation aimed at addressing the issue of compensation for employees was the Cape Employer's Liability Act 35 of 1886, which was replaced by the enactment of the Workmen's Compensation Act 40 of 1905 (Cape of Good Hope).${ }^{94}$ Many of the policy considerations underlying the 1905 Act, as well as succeeding legislative interventions are reflected in the 1904 Report of the Select Committee on Compensation to Workmen.

From its report, it is clear that there was significant concern about securing compensation for injured employees and doing so as "quickly and as cheaply as possible". ${ }^{95}$ It was stated that one of the chief advantages of introducing statutory

88 Hedley 2013: 235-242.

89 Kleeberg 2003: 57-58.

90 Lewis 2012: 140.

91 Ibid; Brodie 2010: 2.

92 Brodie 2010: 2-7.

93 Deakin 2013: 254.

94 The Act is based on the English Act of 1897. See Select Committee 1904: 15, 17. See, also, Jansen van Vuuren 2013: 25.

95 Select Committee 1904: 2. See, also, at 9 and 14, where it is made clear that all relevant parties sought a way to deal with employer and employee disputes as quickly and cheaply as possible and that what is required is "simple machinery" for securing compensation for the injured employee. 
reform would be that it would provide what the law of delict failed to do at the time, namely the speedy provision of a fixed amount of money in lieu of the lost wages and to "ensure that the sum shall be paid with as little litigation as possible". ${ }^{96}$

Another consideration that justified the legislature's intended development of this branch of the law was the fact that, in "ninety-nine cases out of every hundred the workman does not know what he can demand, and if his employer pays him anything at all he considers it as an act of charity. In the great majority of cases he has an action, and does not bring it". ${ }^{97}$

It was also argued that the enactment of legislation would undermine the influence that the defence of contributory negligence had on an employee's potential common-law delictual claim for damages, namely to give the employee an action despite the fact that his negligence contributed towards the accident. ${ }^{98}$

Lastly, the employees sought to improve their safety: ${ }^{99}$

From a workmen's point of view the Bill is a most desirable one in every respect. At the present time workmen are entirely dependent on the generosity of their employers for compensation. Now, gentlemen, it is but natural that an employer of labour should desire to obtain the utmost amount of work for the least possible cost; in the pursuit of that object he is apt to overlook certain precautionary measures which he should take to ensure the safety of his workmen, and we maintain that there should be such an Act so based that it would compel the employer to take these precautionary measures.

Therefore, it seems that the decision by the legislature to develop the law of delict relating to the compensation of employees were motivated by similar policy considerations than those underlying the English legislature's development of law of negligence regarding workplace injuries and diseases.

A similar statute, the Workmen's Compensation Act 36 of 1907, was enacted in the Transvaal. ${ }^{100}$ The Transvaal Act was "almost identical" 101 to the English Workmen's Compensation Act of 1906. The Act applied to the whole country after unification in 1910, but was replaced by the Workmen's Compensation Act 25 of 1914, which, in turn, included a series of industrial diseases following an amendment in 1917 through the Workmen's Compensation (Industrial Diseases) Act

96 Idem at 12.

97 Idem at 14.

98 Ibid. It may be noted that the doctrine of common employment was not considered a part of the South African common law of delict: Waring \& Gillow v Sherborne 1904 TS 340. Accordingly, unlike the position in England, it did not play the same role in motivating legislative change.

99 Select Committee 1904: 64-65.

100 Jansen van Vuuren 2013: 25.

101 Victoria Falls Power Co Ltd v Lloyd NO 1908 TS 1164 at 1172. 
13 of $1917 .{ }^{102}$ Importantly, both these Acts required employees to prove fault on the part of the employer. ${ }^{103}$

In its early form, the Workmen's Compensation Act was ineffective at providing adequate compensation, because employers were not compelled to insure their employees against the risk of workplace injuries. ${ }^{104}$ As a result, employers that did not have insurance could face insolvency if they were held liable for their employees' harm. Also, injured or diseased employees were exposed to the risk that the employer would not be in a position to provide compensation, thereby rendering the employee potentially unable to earn further income. ${ }^{05}$

By 1930, and with the benefit of using the English statute as example, employees, industry and the South African government recognised the need for compulsory insurance. ${ }^{106}$ The 1914 and 1917 statutes were accordingly replaced by the Workmen's Compensation Act 59 of 1934, which provided for a system of compensation to be paid by the employer if an employee suffered harm as a result of an accident arising in the course and scope of his employment. Pursuant to the passing of the Act, employees were no longer required to prove fault on the part of the employer to obtain compensation. ${ }^{107}$ Importantly, the Act made insurance compulsory through private companies rather than a state fund favoured by workers and trade unions. ${ }^{108}$ The office of the Compensation Commissioner was established and tasked with the mediation of compensation settlements between employees and employers that was ultimately funded through the compulsory insurance obtained by employers. ${ }^{109}$

The Workmen's Compensation Act 30 of 1941 replaced the 1934 Act and introduced a new system of compensation by establishing a state "accident fund" 110 to which all employers would contribute on the basis of employer's wage budgets ${ }^{111}$ and from which employees were to be compensated. ${ }^{112}$ Employees were entitled to compensation from the fund if they could prove that they had suffered harm as a result of an "accident arising out of and in the course of ... employment and resulting in a personal injury". ${ }^{113}$ While the Act established a compensation fund, it

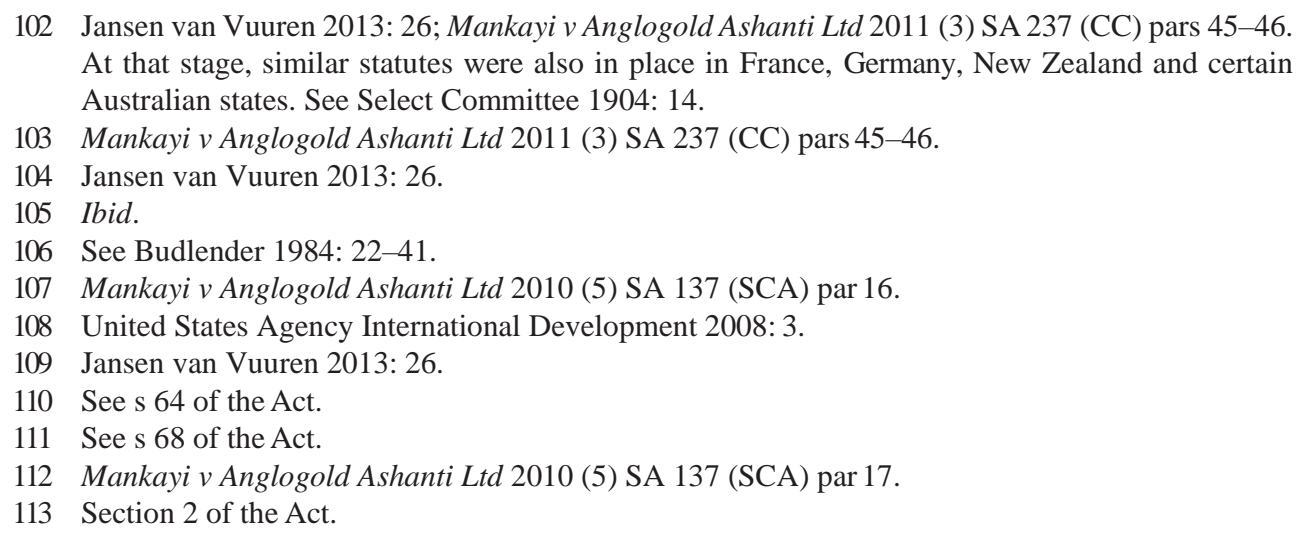




\section{BERNARD WESSELS}

also indemnified employers against potential delictual claims that employees may have had against them. ${ }^{114}$ In $R v$ Canquan,,${ }^{115}$ the court summarised the purpose of the Act by stating that it was "designed to protect the interests of employees and to safeguard their rights, and its effect is to limit the common law rights of employers and to enlarge the common law rights of employees".

COIDA repealed the Workmen's Compensation Act and came into operation in 1994. It provides for the compensation of employees injured in accidents ${ }^{116}$ that arose out of and in the course of their employment, ${ }^{117}$ or who contracted occupational diseases. ${ }^{118}$ In accordance with section 15 of the Act, a statutory compensation fund was established to which employers are required to contribute ${ }^{119}$ and from which compensation and other benefits are paid to employees. ${ }^{120}$ In addition to establishing a fund from which an employee may obtain limited compensation, section 35(1) of the Act abolished the employee's common-law right to institute a delictual claim against his employer for any harm resulting from accidents suffered during the

114 Section 7: “(a) [N]o action at law shall lie by a workman or any dependant of a workman against such workman's employer to recover any damages in respect of an injury due to accident resulting in the disablement or the death of such workman; and (b) no liability for compensation on the part of such employer shall arise save under the provisions of this Act in respect of any such disablement or death."

1151956 (3) SA 355 (E) at 368

116 "Accident" is defined as an "accident arising out of and in the course of an employee's employment and resulting in a personal injury, illness or the death of the employee".

117 See MEC for Health v DN 2015 (1) SA 182 (SCA) for a discussion on the course and scope of employment requirement within the context of COIDA. It may be noted that, apart from COIDA and its antecedent legislation, which relates to the interests of all employees in industry generally (including commerce and services), another strand of legislative development concentrated specifically on the interests of mineworkers. The Occupational Diseases in Mines and Works Act 78 of 1973 (and its predecessors) was a legislative response to the deleterious diseases contracted by mineworkers. Its history may be briefly summarised as follows: The Miners' Phthisis Allowances Act of 1911 was first enacted in 1911, and succeeded in 1912 by the Miners' Phthisis Act of 1912. The 1912 Act was amended by the Miners' Phthisis Amendment Act of 1914. The Miners' Phthisis Amendment Act of 1914 was succeeded by the Miners' Phthisis Act of 1916. It repealed parts of the 1912 Act and the whole of the Miners' Phthisis Amendment Act of 1914. The Miners' Phthisis Acts Consolidation Act of 1925 was enacted in 1925 and was in turn repealed by the Silicosis Act of 1946. The Pneumoconiosis Act of 1956 superseded the Silicosis Act. The 1956 Act was superseded by the Pneumoconiosis Compensation Act of 1962. In 1973, the Occupational Diseases in Mines and Works Act 78 of 1973 repealed previous legislation and consolidated the law relating to the payment of compensation in respect of certain diseases contracted by persons employed in mines and work. See, further, Mankayi v Anglogold Ashanti Ltd 2011 (3) SA 237 (CC) pars 26-35.

118 See $\mathrm{s} 65$ of COIDA.

119 Idem s 87.

120 Idem $\mathrm{s} 16$. 
course and scope of the employment. ${ }^{121}$ When instituting his statutory claim against the compensation fund, an employee is not required to prove fault. ${ }^{122}$

In the leading judgement on the matter, Jooste v Supermarket Trading (Pty) Ltd, the Constitutional Court described this development as follows: ${ }^{123}$

The Compensation Act supplants the essentially individualistic common-law position, typically represented by civil claims of a plaintiff employee against a negligent defendant employer, by a system which is intended to and does enable employees to obtain limited compensation from a fund to which employers are obliged to contribute.

As was the case with motor vehicle accidents, the establishment of a statutory compensation fund appears to undermine the idea that compensation should be paid by the person who culpably and wrongfully caused it, in an attempt to thereby correct his wrong. The existence of a compensation fund in this context is therefore similarly not aligned with the so-called corrective justice explanation for the law of delict. ${ }^{124}$ Notwithstanding, it is successful in achieving the function set out by the law of delict - compensation of harm. Arguably, more injured and diseased employees receive compensation from the fund than would otherwise have been the case if they were required to institute common-law delictual claims against their employers.

Against this background, it may be said that the development of the law of delict by the enactment of legislation that provides compensation for workplace-related injuries and diseases may be regarded as a response to the risk of injury to which the employee is exposed as a result of his employment, as well as the potential risk of not being able to recover any compensation for the harm that is suffered once the risk materialises. In Jooste v Supermarket Trading (Pty) Ltd, ${ }^{125}$ the Constitutional Court confirmed the role of risk and remarked that, in the absence of any legislation "there would be no guarantee that an award would be recoverable because there would be

121 Section 36 of the Act preserves and regulates an employee's rights against a third party whomay incur liability to the employee.

122 Although the Act therefore continues its predecessor's abandonment of the fault requirement, it does play a limited role. Section 56(1) of the Act provides that, if a person has met with an accident or contracted an occupational disease owing to his or her employer's negligence, the employee may apply to the commissioner to receive increased compensation in addition to the compensation normally payable in terms of this Act.

1231999 (2) SA 1 (CC) par 15. See, also, MEC for Education, Western Cape Province v Strauss 2008 (2) SA 366 (SCA) pars 11-12; Healy v Compensation Commissioner 2010 (2) SA 470 (E) par 11; Sanan v Eskom Holdings Ltd 2010 (6) SA 638 (GSJ) par 8; MEC for Health, Free State v DN 2015 (1) SA 182 (SCA) pars 6-7; Thomas v Minister of Defence and Military Veterans 2015 (1) 253 (SCA) par 6.

124 This issue falls outside the scope of the current contribution, but for an overview of some of the aspects related to the function of the contemporary South African law of delict, see Fagan 2012: 130-155. See, also, Wessels 2018: 334-338.

1251999 (2) SA 1 (CC) par 15. 
no certainty that the employer would be able to pay large amounts in damages. It must also be borne in mind that the employee would incur the risk of having to pay the costs of the employer if the case were lost".

The exposure to risk has also played a significant role in the adoption of workplace legislation in foreign jurisdictions. The adoption of the no-fault based legislation to compensate injured and diseased employees is "consistent with a widespread moral idea that it is not unjust to impose a strict liability on those who cause loss while taking risks in pursuit of commercial profit, even where the risk is unforeseeable or cost-justified". ${ }^{126}$

In conclusion, it appears that the leading policy consideration underlying legislative development of the law of delict in this field is the attempt to ensure that employees will receive compensation, albeit limited, in respect of the materialisation of an employment risk during the course and scope of employment. ${ }^{127}$ It appears that the notion of enterprise liability best explains the reason for imposing liability for harm on employers specifically.

\section{Defective consumer products}

The design, manufacture, distribution and sale of products and services are, generally, central to the wealth and welfare of any society, but bring about disease, injury and even death for a wide range of individuals. ${ }^{128}$ The rise of industrialisation in the nineteenth century and consumerism in the twentieth century led to a substantial increase in the manufacturing and distribution of consumer products. ${ }^{129}$ This meant that, more than ever before, consumers were being exposed to an unremitting series of manufactured goods. Because technology grew more sophisticated and was often coupled with expertise, consumers knew very little about the products that reached them. It is therefore unsurprising that many of these products posed a significant risk to the well-being of consumers who chose to make use of them. ${ }^{130}$ Even where the risk of harm was not particularly great, it was accepted that, should it materialise, the harm suffered by the consumer would be severe. ${ }^{131}$

In response to the rise in consumer products, the growing risk of exposure to harm and the difficulty of holding manufacturers liable for the harm suffered by

126 Stapleton 1994: 195.

127 Cane 2013: 332.

128 Van Eeden 2013: 367. Some of the defective consumer products that have caused disease, injury and death within this context include pharmaceutical products and other defective medical devices, as well as manufactured products (such as motor vehicles, household items and military devices) and contaminated food products.

129 Stapleton 1994: 9-16.

130 Van Eeden 2013: 370.

131 Van Gerven, Larouche \& Lever 2000: 599. 
consumers as a result of defective products, the South African legislature introduced a strict liability regime for harm suffered as a result of defective products when it enacted the CPA. ${ }^{132}$ Set out below is a brief overview of the historical development, which culminated in the statutory reform of the law of delict in this context.

As is the case with the rise of product liability as a distinct area of the law in a variety of other jurisdictions, this development in the South African law may be traced back to progress made by the courts in the United States of America (USA). Indeed, the judicial development of the law by US courts is generally regarded as the precursor to the global increase of legislative intervention aimed at compensating victims of defective consumer products. ${ }^{133}$

As will be discussed in greater detail below, the American judicial innovations enabled these victims to litigate against the sellers and manufactures of defective products through alterations of the existing tort or contract law. ${ }^{134}$ The courts' approach was ultimately captured in the American Law Institute's Second Restatement of Torts in 1965, after which, as Reimann ${ }^{135}$ describes -

in the 1960s and 1970s, the principle of strict product liability swept through the United States, and became the rule in most, though not all, states of the Union. European scholars and policy makers watched this development with great interest. In part, they were fascinated by the activism of the American courts, which fashioned a new consumer protection regime.

Because the rise of the strict liability regime is generally regarded as originating within the American courts, ${ }^{136}$ special attention will be placed on the judicial expansion of liability for defective consumer products within this jurisdiction.

The economic expansion that industrialisation produced - in especially the USA - was accompanied by a significant increase in the volume of consumer transactions. ${ }^{137}$ The types of products manufactured and sold by way of these transactions posed a significantly higher risk of bodily injuries or property damage than was the case earlier during the nineteenth century: ${ }^{138}$

Sometimes the nature of the new type of good made inspection difficult or impossible at least without expert technical advice, which was often in short supply. Even if the intrinsic nature of the good did not produce this situation, the volume of transactions and the new forms in which products were packaged and delivered often did. But most importantly of all, inspection was often rendered difficult if not impossible - at least for commercial buyers

132 The Act came into effect in 2010.

133 Reimann 2015: 251. See, also, Van Eeden 2013: 1-5, 21-22; Reimann 2003: 756, 761; Stapleton 1994: 3-36.

134 Reimann 2015: 251.

135 Ibid. See, also, Van Eeden 2013: 1-5, 21-22; Reimann 2003: 756-761; Stapleton 1994: 3-36.

136 Ibid.

137 Stapleton 1994: 10.

138 Idem at 11. 
in the chain - by the increasing number of contracts formed between parties acting at a distance, in some cases before the relevant goods had come into existence, and the speed at which goods were passed down the lengthening commercial chain.

Most American consumers who were harmed by manufactured products were faced with a stumbling block; because they were not contractually linked to the manufacturer in question, they lacked a contractual remedy. ${ }^{139}$ In cases where a consumer did have the option of instituting a contractual claim against a manufacturer, there was the possibility that it did not have sufficient funds or insurance to compensate the injured consumer for the harm suffered. In other words, much like the victims of motor vehicle accidents or those who suffered from injuries or diseases sustained during the course and scope of their employment at the turn of the previous century, consumers were exposed to an increased risk of harm and its accompanying risk of receiving limited or no compensation.

To deal with this problem, American courts developed contract law in a series of cases in the early twentieth century ${ }^{140}$ so that the requirement of privity of contract was partially relinquished and less reliance was placed solely on contract to protect consumers from harm as a result of defective products. ${ }^{141}$ The courts expanded the liability of manufacturers by relying on the idea of a transmissible warranty that goods are free of defects. ${ }^{142}$ As a result, the action for breach of warranty was ultimately made available not only to the immediate purchaser of a product, but also to other persons who may reasonably have expected to use, consume or be affected by the goods. ${ }^{143}$

In Greenman v Yuba Products, ${ }^{144}$ the Supreme Court of California took the first steps to move away from the contractual route and laid down a principle of strict liability in tort for defective consumer products. ${ }^{145}$ The gradual development of the manufacturer's liability in American courts ultimately led to the adoption in 1965 of section 402A of the American Law Institute's Restatement (Second) of Torts, which purported to provide a strict liability regime for defective products. ${ }^{146}$

139 See Stapleton 1994: 9-16; Loubser \& Reid 2012: 4-9.

140 Deakin, Johnston \& Markesinis 2013: 590-607.

141 See Loubser \& Reid 2012: 24.

142 Ibid.

143 The abandonment of privity of contract in favour of protecting a broader consumer interest is reflected in the well-known judgement of Traynor J in Escola v Coca-Cola Bottling Co of Fresno $24 \mathrm{Cal} 2 \mathrm{~d} 453$, where it was noted that privity should be abandoned and that the public policy considerations underlying the implied warranty of merchantability should be used to construct an independent and strict liability for defective products in tort. Further extension took place in Henningsen v Bloomfield Motors Inc 32 NJ 358, 161 A 2d 6 (1960). See, also, Loubser \& Reid 2012: 24; Stapleton 1994: 21.

14459 Cal 2d 57 (1963).

145 Howells 2006: 579.

146 Loubser \& Reid 2012: 7. 
During this time, victims of defective consumer products in European jurisdictions generally had to seek refuge in the law of contract and tort law if they intended to seek compensation for their harm. ${ }^{147}$ In the UK, for example, Stapleton writes that "[1]ittle changed in the relevant UK common law from the removal of the privity barrier to tort claims for physical loss in Donoghue v Stevenson (1932) until the turn of the 1960s". ${ }^{148}$

A victim of a defective product could thus sue a retailer for the harm to his person or property under the warranties as to the quality of the product implied under the Sale of Goods Act. ${ }^{149}$ However, courts continued to give effect to the privity requirement in contract law, and a third party who suffered harm, regardless of the foreseeability thereof, was therefore not entitled to sue for breach of contract. ${ }^{150}$

Further, consumers who intended to sue someone other than the immediate seller of the defective product, could do so only in the event that such a person had made an express warranty with regard to the quality of the product. ${ }^{151}$ Despite the House of Lord's confirmation in Donoghue $v$ Stevenson ${ }^{152}$ that the ultimate consumer had a tort claim against the ultimate manufacturer of the defective product, the plaintiff was still required to prove negligence. ${ }^{153}$ The end result therefore was that, compared to the developments initiated by US courts, victims of defective consumer products in the UK received considerably less protection against the risk of harm that manufactured products carried with them.

The legal position was similar in Germany, where, prior to the legislature's ultimate intervention in $1989,{ }^{154}$ liability for harm arising from defective consumer products was regulated by tort and contract law. ${ }^{155}$ In 1956, the German Bundesgerichtshof ${ }^{156}$ denied the driver of a new bicycle a remedy in tort when the handlebar broke because of the technical deficiency of the steel, resulting in the plaintiff's bodily injuries. The court held that the weakness in the steel was practically undiscoverable and that the manufacturer had not breached its duty of care and was therefore not negligent. However, in 1968, the same court brought about a "fundamental change" 157 when

147 See, generally, Stapleton 1994: 37-45; Markesinis \& Unberath 2002: 748-749, 881-883; Reimann 2015: 251-253.

148 Stapleton 1994: 37.

149 Ibid; Deakin, Johnston \& Markesinis 2013: 590.

150 Deakin, Johnston \& Markesinis 2013: 590.

151 Stapleton 1994: 37-38.

152 [1932] AC 562.

153 Deakin, Johnston \& Markesinis 2013: 590.

154 The Products Liability Act, 1989.

155 Grote 2008: 111.

156 BGH VIZR 36/55 "Der Betrieb” 1956 at 592.

157 Fairgrieve 2005: 100. 
it held that, "if the cause of the damaging factor can only be located within the premises of the producer, his negligence is presumed". ${ }^{158}$

This judicial attempt at developing the law to assist the victim of a defective consumer product in finding compensation for his harm was borne out of considerations related to fairness: "It would be unjust for the victim ... to be forced to prove circumstances within the enterprise which would only allow the conclusion that the producer was negligent. The factory of the manufacturer is not accessible to him. It is therefore the defendant who must show that he did not act negligently." 159 This change in the legal position "was no doubt influenced by the developments in the USA ... and the adoption of s 402A of the Restatement of Torts Second". ${ }^{160}$

Despite the judicial development to assist victims of defective products in claiming compensation, Taschner maintains that the German courts provided only "half-way solutions [which] showed the need to change the law, [and that] they were not definite ways to reach a satisfactory result". ${ }^{161}$ Similarly, writing about European jurisdictions generally, Reimann states that the "courts in Western Europe struggled to protect victims of defective products without openly breaking with the traditional rules of contract ... and tort". ${ }^{162}$

Dissatisfaction concerning the inability of existing liability regimes to provide redress for consumers therefore grew steadily. ${ }^{163}$ The concern was amplified by the thalidomide drug disaster of the 1960s. During 1961, it was recognised that the pregnancy drug, thalidomide, had caused birth defects in the children of some of its users. Almost 8000 children in over 30 countries were affected. ${ }^{164}$ The difficulties that were experienced by the deformed children in obtaining compensation from the manufacturer assisted in focusing attention on the uncertainties and difficulties experienced when instituting a tort claim for negligence, as did the slow and expensive process of litigation. ${ }^{165}$

Therefore, at the time that proposals for a European Community Directive on Products Liability were first considered in the 1970s, it was not possible to speak of product liability law as such in either Germany or England. ${ }^{166}$ In both countries, the legislature intervened by adopting product liability legislation subsequent to the Member States of the European Community adoption of Council Directive 85/374/EEC on 25 July 1985. The Directive had the "dual aim of harmonising the conditions of

158 Taschner 2005: 155, 159.

159 Idem at 159. See, also, Reimann 2015: 252.

160 Fairgrieve 2005: 100.

161 Taschner 2005: 159.

162 Reimann 2015: 252.

163 Loubser \& Reid 2012: 9.

164 Stapleton 1994: 42.

165 Ibid.

166 Deakin, Johnston \& Markesinis 2013: 590; Markesinis \& Unberath 2002: 748-749, 881-883. 
competition in the internal market and ensuring adequate protection for victims of unsafe products across the Member States". ${ }^{167}$ Broadly, the directive provides that, where someone can prove that his bodily integrity or property has been physically harmed by a defective product that was put into circulation in the ordinary course of business, he can institute a claim against its manufacturer, importer, own-brand supplier or a mere supplier, without having to prove negligence against any specific party or that the defendant caused the defect. ${ }^{168}$

In England, the enactment of the Consumer Protection Act of 1987 can be traced back to this directive and the Act seeks to give effect to its principles. Generally, this Act, as read with the directive, imposes strict liability on manufacturers, distributors and retailers for harm arising from defective products. Similarly, in Germany, the Products Liability Act of 1989 followed the 1985 Directive and introduced a strict liability on manufacturers for harm arising from defective products. ${ }^{169}$

In contrast to the US, UK and German legislatures, the South African legislature took significantly longer before it finally decided to develop the delictual principles relating to harm suffered as a result of defective products. The CPA was enacted in 2008 and only became operative in 2010. Section 61(1) of the Act introduced a framework in terms of which producers, importers, distributors or retailers may be held strictly liable for bodily injuries or property damage brought about by the supply of unsafe goods or by a product failure, defect or hazard, or by inadequate instructions or warnings for the use of certain goods.

Prior to its enactment, however, the legal position was that a consumer who suffered harm as a result of a defective product could institute either a contractual claim against the seller of the product in question or, alternatively, pursue a delictual remedy against a member of the supply chain. The South African law of contract, however, did not undergo a similar development with regard to the extension of warranties, and consumers who pursued this route remained bound by the principle of privity of contract. ${ }^{170}$ In terms of the South African common law of contract, a manufacturer may be held liable to a purchaser for breach of warranty on the basis of agency or a contract for the benefit of a third party. ${ }^{171}$ However, these contractual mechanisms ultimately have limited practical effect in assisting consumers who have suffered harm as a result of a defective product against manufacturers. ${ }^{172}$

On the other hand, a plaintiff who instituted a delictual claim ${ }^{173}$ is bound to prove all of the common-law elements for delictual liability. In the context of defective

167 Loubser \& Reid 2012: 9.

168 See Stapleton 1994: 49.

169 Markesinis \& Unberath 2002: 748.

170 Hutchison \& Pretorius 2012: 21-32. See, also, Van Eeden 2013: 73-87, 372; Loubser \& Reid 2012: 23-35.

171 Loubser \& Reid 2012: 24; Dendy 2014: par 175.

172 Loubser \& Reid 2012: 24; Van Rensburg, Lotz \& Van Rhijn 2014: par 425.

173 Loubser \& Reid 2012: 24: An action based on the manufacturer's pre-contractual representations. 
consumer products, the elements of fault (in the form of negligence), causation ${ }^{174}$ and fault ${ }^{175}$ are particularly difficult to prove. In Wagener $v$ Pharmacare Ltd; Cuttings $v$ Pharmacare Ltd (Wagener), ${ }^{176}$ the SCA was requested to develop the common law of delict by doing away with the requirement of fault. ${ }^{177}$ However, the court refrained from doing so, stating that any reform of the law of delict in this context was better left to the legislature. ${ }^{178}$

The apparent lack of an effective remedy to compensate harm suffered by a consumer may therefore be said to have been a convincing policy-based consideration for the legislative development of this branch of the law, both in South Africa and elsewhere. Of course, as stated above, a desire for an effective remedy was the result of the risk of harm consumers were exposed to by especially modernised, technologically-advanced manufacturers and the accompanying risk of potentially receiving no compensation should the harm materialise.

The legislative development of the delictual remedies in respect of harm caused by defective consumer products occurred through the introduction of a strict liability regime for producers, importers, distributors and retailers. The most convincing policy-based justification for the legislature's development of the law of delict may arguably be found in the notion of enterprise liability. Consumers are exposed to risks inherent to certain products from which manufacturers stand to make a profit. Therefore, the costs of accidents should be imposed on the manufacturers, who, additionally, often are best placed to take steps to avoid the risk of damage (by taking precautions at the design and manufacturing stages of production) ${ }^{179}$ or to minimise its effects (through the adoption of insurance or through pricing of products). ${ }^{180} \mathrm{This}$ point has also been illustrated in the landmark US decision, Escola v Coca-Cola Bottling Co: ${ }^{181}$

Even if there is no negligence, however, public policy demands that responsibility be fixed wherever it will most effectively reduce the hazards to life and health inherent in defective products that reach the market. It is evident that the manufacturer can anticipate some hazards and guard against the recurrence of others, as the public cannot. Those who suffer injury from defective products are unprepared to meet its consequences. The cost of an injury and the loss of time or health may be an overwhelming misfortune to the person injured, and a needless one, for the risk of injury can be insured by the manufacturer and distributed among the public as a cost of doing business. It is to the public interest to discourage the marketing of products

174 See idem at 53-55 for the difficulties relating to proving causation in this context.

175 See idem at 46-50 for the difficulties relating to proving fault in this context. See, also, Wagener $v$ Pharmacare Ltd; Cuttings v Pharmacare Ltd 2003 (4) SA 285 (SCA).

1762003 (4) SA 285 (SCA) par 10.

177 Idem pars 17, 27-30.

178 See, also, part 2.5 infra.

179 Deakin, Johnston \& Markesinis 2013: 590-591.

180 Loubser \& Reid 1994: 5; Stapleton 1994: 162-184.

$18124 \mathrm{Cal} 2 \mathrm{~d} 453$ (1944) at 462 (emphasis added). 


\title{
LEGAL AND PUBLIC POLICY CONSIDERATIONS
}

\begin{abstract}
having defects that are a menace to the public. If such products nevertheless find their way into the market it is to the public interest to place the responsibility for whatever injury they may cause upon the manufacturer, who, even if he is not negligent in the manufacture of the product, is responsible for its reaching the market. However intermittently such injuries may occur and however haphazardly they may strike, the risk of their occurrence is a constant risk and a general one. Against such a risk there should be general and constant protection and the manufacturer is best situated to afford such protection.
\end{abstract}

In conclusion, it may be argued that, as was the case with statutory intervention in the area of motor vehicle accidents and workplace-related injuries and diseases, the most prominent underlying consideration for the development of the fault-based common law of delict in relation to harm suffered as a result of a defective product is the creation of a risk of harm and the additional risk that the injured consumer may not find compensation as a result of an insolvent manufacturer, evidentiary difficulties or ineffective legal remedies. The introduction of strict liability by the legislature has been justified by the notion of enterprise liability in the context of both occupational injuries and diseases, as well as defective consumer products. ${ }^{182}$

At the advent of the previous century, the protection from the risk of potential harm was still largely assumed to be a matter that people had to attend to themselves. Upon the materialisation of such a risk, people were similarly presumed to take responsibility for obtaining compensation for their harm by instituting legal action against the wrongdoer. ${ }^{183}$ In other words, those who suffered harm as a result of the culpable wrongdoing of others were largely dependent on the remedies available in the common law of delict. Generally, this meant that the victims of harm had to find the time and funds to institute legal proceedings against a wrongdoer and provide sufficient evidentiary proof that the wrongdoer's culpable conduct was indeed the cause of their harm.

However, over the course of the twentieth century, a shift gradually occurred and the law of delict was developed by the South African legislature. The shift originated in the context of accidents that took place in the workplace, which may be said to have been characterised by an initial reluctance to regulate the behaviour of employers, ${ }^{184}$ and the court's original individualistic approach, which saw employers being held liable for workplace accidents only in the event that the victim could prove personal fault on the part of the employer. ${ }^{185}$ The development of the law of delict, as driven by the South African legislature, ultimately led to a growing demand for workplace safety, legal certainty and, most importantly, a cheaper and quicker way of compensating employees who suffered harm when an employment-related risk of harm materialised. Although there were other compelling considerations, it

182 See Stapleton 1994: 20.

183 For a comparative perspective, see Hedley 2013: 235.

184 Select Committee 1994: 64-65. See, also, Hedley 2013: 236.

185 See, further, Hedley 2013: 237. 
may be argued that, ultimately, the employees' exposure to an ever-increasing risk of harm and the accompanying risk of not being able to receive compensation provided the predominant consideration for the legislature's decision to intervene.

Similarly, as a result of the increase in the number of motor vehicles during the course of the twentieth century, the number and frequency of motor vehicle accidents grew significantly. Perhaps more than occupational accidents, this upsurge exposed road users to a substantial risk of harm and an accompanying risk of receiving no compensation in the event that the risk should materialise. Again, the legislature intervened by developing the law of delict. This was initially done by retaining the motor vehicle accident victim's delictual remedy against a wrongdoer while also introducing the notion of compulsory third party insurance. ${ }^{186}$ In doing so, the legislature shifted the responsibility to compensate the motor vehicle accident victim to a source other than the wrongdoer. The legislature's desire to address the risk of receiving no compensation also saw it further develop the law relating to motor vehicle accidents by replacing the system of compulsory third-party insurance with a centralised compensation fund, financed through fuel levies.

Recently, the legislature abolished the motor vehicle accident victim's right to a common-law delictual remedy in respect of the harm not covered by the RAF Act. Although such a legislative development was held to be constitutionally valid, it arguably undermines the initial legislative project of ensuring the compensation of the victim's harm in the case of a risk eventuating, and is furthermore indicative of the legislature's attempt to offer protection also to the wrongdoer. The legislature has attempted to justify these amendments as constituting part of greater reform towards a comprehensive social security for all individuals.

The statutory development of the law of delict by the introduction of a strict liability regime in respect of producers, importers, distributors or retailers was also, to a great extent, driven by the dramatic increase in the production of consumer goods, which brought about an ever-increasing risk of harm associated with a modern, mechanised society that produces potentially hazardous products.

Although the utility of motor vehicle transport, increased labour forces and a growing manufacturing sector is clearly visible, the benefit is accompanied by an amplified risk of harm. The South African legal system produced a solution in which these activities was permitted, but only on condition that the most appropriate enterprise was saddled with the cost of the risks they produced. ${ }^{187}$

Attention has already been drawn to the expansion of the state's delictual liability for harm that arises from crime. ${ }^{188}$ The development is disquieting, also from a crimeprevention perspective because, with more of available tax-payer funds being spent

186 Idem at 243: "Third-party insurance was first offered to carriage drivers in 1875, and to motorists in 1896." Furthermore, compulsory insurance was introduced by the Road Traffic (Compensation for Accidents) Bill in 1934.

187 See, also, Markesinis \& Unberath 2002: 716.

188 See the introduction to this contribution in part 1 supra. 
on litigation and the payment of full compensation to crime victims, less of the funds are directed to promoting safety and to preventing crime. In turn, this creates greater possibilities for the further extension of the state's delictual liability. In otherwords, the current judicial trend indirectly contributes to the increased risk of crime by diminishing available resources intended for crime prevention. At the same time, the recent development responds to the risk of receiving no or limited compensation in the event of suffering from crime - but only in respect of a limited number of crime victims who are able to institute litigious proceedings against the state. Therefore, the ongoing tendency to expand the state's delictual liability indirectly contributes to the increased likelihood of being a victim of crime, while it provides a compensatory solution only to those who are capable of proving liability in court.

Viewed against the background of statutory development, which highlights the potentially more effective victim compensation strategy that exists through the legislative reform of the law of delict, the current judicial development pertaining to crime victim compensation appears unattractive. ${ }^{189}$

\section{The role of the Constitution and the need to promote the constitutional right to social security}

In this part of the contribution, attention will be given to the role of the Constitution of the Republic of South Africa, 1996 (Constitution) in justifying the statutory development of the law of delict. As discussed in greater detail below, the statutory development of the law of delict is examined to establish the role that the constitutional right to social security has fulfilled as a legal consideration justifying the legislative intervention in the law of delict. Particular attention is given to the development of the area of the law that relates to motor vehicle accidents and occupational injuries and diseases.

Before continuing, it would be appropriate to summarise the salient provisions of the Constitution and to explain how this consideration differs from the one discussed in part 2.1 above. The Constitution is the supreme law of the country, ${ }^{190}$ central to the country's legal system and it determines the validity of all law, including the law of delict. The Bill of Rights applies to all law and binds the legislature, the executive, the judiciary and all organs of state. ${ }^{191}$ It also applies to the conduct of natural persons and juristic persons, when appropriate. ${ }^{192}$ The Constitution also enjoins every court, tribunal or forum to promote the spirit, purport and objects of the Bill of Rights when

189 Some of the negative aspects related to the expansion of state delictual liability for harm arising from crime has been highlighted in the introduction to this contribution - see part 1 supra. In this regard, see Wessels 2018: 31-127 for a thorough discussion of that development.

190 Section 2 of the Constitution.

191 Idem s 8(1).

192 Idem s 8(2). 
interpreting any legislation and when developing the common law. ${ }^{193}$ Section 7(2) of the Constitution imposes upon the state a positive duty to protect and promote the rights contained in the Bill of Rights. Importantly, section 27(1)(c) ${ }^{194}$ refers to the right to social security and section $27(2)^{195}$ imposes upon the state a mandatory duty to take reasonable legislative and other measures, within its available resources, to achieve the progressive realisation of each of these rights.

Further, the promotion of social security as a policy consideration should be distinguished from the need to combat risk. ${ }^{196}$ The promotion of social security is not only focused on addressing the risk of a specific type of harm and the accompanying risk of potentially receiving no or limited compensation. Legislation that is aimed at promoting social security typically casts the net wider and attempts to support individuals with no or low income, to provide adequate standard of living and to put in place a social safety net against destitution. ${ }^{197}$ As alluded to in its policy paper regarding the proposed RABS, the right to a social security system does not focus only on compensating harm that arises within a specific context. ${ }^{198}$ Instead, social security arrangements consist of a range of collective and individual social, fiscal, occupational and welfare measures of private, public and mixed origin, aimed at providing social cover to members of society. ${ }^{199}$ In other words, the consideration discussed in this part of the contribution is not the same as the one discussed in part 2.1 above. While the latter concentrated solely on the issue of compensation of the victim's harm (once a particular risk has materialised), the promotion of the constitutional right to social security has a broader scope that embraces other noncompensatory objectives, including empowering the historically disadvantaged, ${ }^{200}$ promoting fundamental human rights (particularly human dignity), ${ }^{201}$ addressing past injuries $^{202}$ and seeking to provide an adequate standard of life to all individuals. ${ }^{203}$

193 Idem s 39(2).

194 This section states that everyone has the right to access to "social security, including, if they are unable to support themselves and their dependants, appropriate social assistance".

195 This section states that the "state must take reasonable legislative and other measures, within its available resources, to achieve the progressive realisation of each of these rights".

196 See, also, part 2.1 supra.

197 Department of Transport 2011: 7-8.

198 Idem at 5-6.

199 Ibid.

200 In doing so, the legislation addresses poverty and social exclusion, which may be regarded as a key to social protection. It also enhances other constitutional values and principles, such as equality, non-sexism and non-racism. See Olivier, Smit \& Kalula 2003: 35.

201 Idem at 36: "There is some Constitutional Court authority for the view that social security-related rights are aimed at more than simply restoring material disadvantage. In Grootboom, the court emphasised the strong link between human dignity and the giving effect to access of adequate housing."

202 Idem at 53: "Fundamental reform of South Africa's social security system aims to redress past injustices, particularly the country's legacy of poverty and equality."

203 See Department of Transport 2011: 5-6. 
Referring to the statutory motor vehicle accident compensation scheme established to cover the risks to which road users are exposed, the Constitutional Court held that it "seems plain that the scheme arose out of the social responsibility of the State. In effect, it was, and indeed still remains, part of the social security net for all road users and their dependants" ${ }^{204}$

During the parliamentary debate concerning the introduction of the 1942 Act and accompanying compulsory third party insurance scheme, it was stressed that, regardless of the accompanying cost that a compulsory third-party insurance system may bring, members of society should realise that the Act "aims at the protection of those who cannot look after themselves". ${ }^{205}$ In particular, the "principle of security"206 was emphasised to ensure protection of the road users' interests and safety. Those in favour of the legislation stressed the impact of injury and disability upon road users: $^{207}$

Those people who were injured are suffering day in and day out in their work; they are unable to look after their families, and because those families have to endure great hardships while the children are young, they cannot enjoy their legitimate share in life. Those are the people we should primarily think of. They must be looked after. The people who are injured must first of all be nursed back to health, which means an enormous amount of work for the hospitals and for the nursing services, and also for the medical services of this country.

Because of its adherence to fault-based liability, the RAF Act, however, has been criticised as a failed system that is "unreasonable, inequitable, unaffordable and unsustainable". ${ }^{208}$ As discussed elsewhere in this contribution, ${ }^{209}$ the requirement for fault has a significantly detrimental impact on the successful pursuit of compensation by a motor vehicle accident victim. In turn, it is argued, a significant amount of those victims are left uncompensated and without the ability to earn income. To deal with this concern, and to provide greater effect to the right to social security, the legislature has proposed the RABS. In Law Society of South Africa v Minister for Transport, ${ }^{210}$ the purpose of the proposed scheme was described as follows:

[T] he ultimate vision is that the new system of compensation for road accident victims must be integrated into a comprehensive social security system that offers life, disability and health insurance cover for all accidents and diseases. [The Minister] acknowledges that a faultbased common-law system of compensation for road accident victims would be at odds with a comprehensive social security model. The intention is therefore to replace the commonlaw system of compensation with a set of limited no-fault benefits which would

2042011 (1) SA 400 (CC) par 17.

205 RAFC 2002: 109.

206 Ibid.

207 Ibid.

208 Department of Transport 2011: 13.

209 See part 2.3 infra.

2102011 (1) SA 400 (CC) pars 45-46. 
form part of a broader social security net as public financial support for people who are poor, have a disability or are vulnerable. ... [The] new scheme is a first step to greater reform.

Furthermore, the policy paper for the RABS makes it clear that the proposed no-fault based compensatory scheme must be understood against the social and economic reality of South African society, which is characterised by great disproportions in income and lifestyle. ${ }^{211}$ The RABS is cognisant of historical disadvantages prevalent in the South African society and is a legislative attempt to develop the existing common law of delict as it relates to compensation of motor vehicle accidents, as well as an attempt to contribute to the state's broader social security reform process. ${ }^{212}$ By removing the requirement of fault, the legislature makes provision that social security benefits will be made available to a wider group of road accident victims, ${ }^{213}$ in the process seeking to provide an adequate standard of life to all citizens. In doing so, the legislature strives to promote the principle of social inclusion, as well as the notion that the "risk of misfortune should become the comprehensive and collective responsibility of society as a whole". ${ }^{214}$

Occupational-injury-and-disease schemes are generally considered to be the oldest form of social security coverage in the world. ${ }^{215}$ It is also regarded as the most widespread system of social security, and if the "various branches of social security from different countries are examined it is clear that almost every country ... has an insurance scheme to cover these risks". ${ }^{216}$ Generally, these schemes give effect to the right to social security by promoting workplace safety and providing compensation, medical care, vocational rehabilitation, and further benefits to employees, as well as survivors' benefits for families of victims of occupational accidents. ${ }^{217}$

As noted above, COIDA introduced significant changes in respect of the protection of employees' rights and, although it did not intend to provide a kind of general health cover for every accident or disease which an employee may suffer from, it may nevertheless be regarded as social security legislation, aimed at the provision of a more equitable compensation dispensation in regard to injuries suffered and diseases contracted by employees. ${ }^{218}$ Specifically, where earlier legislation was based on the principle of individual employer liability as covered by private insurance, the subsequent legislation introduced the principle of no-fault based liability and limited benefits covered by a public scheme. ${ }^{219}$ The introduction of such a scheme, which does not require an employee to prove fault on the part of the employer, weakens

211 Department of Transport 2011: 6-7.

212 Ibid.

213 Ibid.

214 Idem at 7.

215 International Labour Office 2013: passim.

216 Olivier, Okpaluba, Smit \& Thompson 1999: 312.

217 International Labour Office 2013: passim.

218 For example, the exclusion of higher-income earners was removed.

219 Olivier 2012: par 9. 
the likelihood of lengthy and costly legal disputes and provides a more streamlined administrative process for the effective compensation of injured employees. As such, this piece of "social legislation" 220 promotes the social and economic welfare of employees.

Therefore, taking into account that it sought to promote workplace safety, rehabilitate injured or diseased employees and provide compensation to those who have fallen victim to accidents that have occurred during the course and scope of employment, it may be said that the legislative development of a no-fault-based compensation scheme for occupational injuries and diseases in South Africa is an example of the promotion of the constitutional right to social security. ${ }^{221}$

In conclusion, it may be said that social security arrangements consist of a range of collective and individual social, fiscal, occupational and welfare measures of private, public and mixed origin, aimed at providing social cover to members of society and at combating certain risks. The statutory compensation schemes that provide compensation for harm arising from motor vehicle accidents and occupational injuries and diseases constitute a part of the broader social security project in South Africa. These schemes afford a variety of victims the possibility to obtain compensation in a relatively affordable and quick manner and without having to pursue a more costly, time-consuming litigious route. In doing so, they protect people from misfortune, distress and the significant risks to life caused by unemployment, illness, injury, disability and death of a breadwinner, and thereby give effect to the constitutional right to social security.

The Constitution has been particularly important in developing the law of delict by promoting the constitutional right to social security. It may be argued that COIDA and the RAF Act are aimed at giving effect to this constitutional imperative insofar as they afford victims of motor vehicle accidents, workplace injuries and diseases the fullest possible protection of their legal interests. ${ }^{222}$ Furthermore, the proposed nofault-based compensatory model sought to be introduced under the RABS has pertinently been justified on the basis that it seeks to give "effect to the [right to] reasonable access to social security and health care". ${ }^{223}$

The South African legislature's development of the law of delict pertaining to the compensation of accident victims is therefore justified insofar as it addresses

220 In Molefe $v$ Compensation Commissioner [2007] ZAGPHC 365 par 5, Seriti J found that the "Compensation for Occupational Injuries and Diseases Act ... is a social legislation and according to section 39(2) of the Constitution, it must be interpreted in such a manner that the said interpretation promotes the spirit, purport and objects of the social security right as enshrined in section 27(l)(c) of the Constitution".

221 Myburgh, Smit \& Van der Nest 2011: 43.

222 Olivier, Khoza, Jansen van Rensburg \& Klinck 2003: 49-119; Van Eeden 2013: 92; Law Society of South Africa v Minister for Transport 2011 (1) SA 400 (CC).

223 Law Society of South Africa v Minister for Transport 2011 (1) SA 400 (CC). 
particular and pervasive social risks to which all members of society are exposed and responds to the broader constitutional project to promote social security.

\section{Evidentiary problems with applying the common-law requirement of fault}

Although the law of delict recognises exceptional circumstances where it is not required, a plaintiff must, generally, prove fault. This means that, first, the victim is required to prove that the wrongdoer had the capacity to be at fault. ${ }^{224}$ To do so, a plaintiff must prove that the defendant had the mental ability to distinguish between right and wrong and to act in accordance with that distinction. ${ }^{225}$ If the wrongdoer is shown to be accountable, the plaintiff must prove that the wrongdoer acted either intentionally or negligently. With regard to the former, it must be proven that the defendant had the direction of will to cause him harm and that the wrongdoer was conscious of the wrongfulness of his act. ${ }^{226}$ In respect of the latter, the plaintiff must prove that the wrongdoer's conduct failed to measure up to the standard of the objective reasonable person. ${ }^{227}$

Despite strong arguments that may be raised in support of the departure from fault-based liability, the South African courts have reiterated the requirement for proving fault when establishing delictual liability. ${ }^{228}$ Despite the fact that there may be convincing reasons in favour of such a general position, the South African legislature has nevertheless elected to develop the law of delict by abolishing the fault requirement in specific contexts. In this part of the contribution, consideration is given to the reasons that have justified the legislative development in these instances.

In its report, the RAFC, tasked with conducting an inquiry into and making recommendations regarding a "reasonable, equitable, affordable and sustainable system for the payment by the Road Accident Fund of compensation or benefits in the event of the injury or death of persons in road accidents in the Republic", ${ }^{229}$ noted that it "is increasingly felt that fault cannot really be determined accurately and there is also a growing social concern for accident victims regardless of the role they played in causing the accident". ${ }^{230}$

224 Neethling \& Potgieter 2015: 131; Loubser \& Midgley 2017: 138-177.

225 Eskom Holdings Ltd v Hendricks 2005 (5) SA 503 (SCA) at 511.

226 Le Roux v Dey; Freedom of Expression Institute Amici Curiae 2011 (3) SA 274 (CC).

227 Sea Harvest Corporation (Pty) Ltd v Duncan Dock Cold Storage (Pty) Ltd 2000 (1) SA 827 (SCA); Kruger v Coetzee 1966 (2) SA 428 (A); Loureiro v Imvula Quality Protection (Pty) Ltd [2014] ZACC 4.

228 Oppelt v Department of Health, Western Cape 2016 (1) SA 325 (CC); Jacobs $v$ Transnet Ltd t/a Metrorail 2015 (1) SA 139 (SCA); H v Fetal Assessment Centre 2015 (2) SA193 (CC).

229 RAFC 2002: 1.

230 Idem at 119. 
In the RABS policy paper dealing with the potential legislative intervention in the law of delict in the context of motor vehicle accidents, the Minister states that this requirement may lead to a delay in providing victim compensation, because it is often necessary to resort to litigation to obtain clarity on the question of fault. ${ }^{231}$ This, in turn, results in extensive legal costs for both the accident victim and the RAF. ${ }^{232}$ During the delay, victims have to pay for medical and other expenses themselves and, if they are disabled, they are not in a position to pursue gainful employment, which means that their families could also suffer. ${ }^{233}$ In a developing country, such as South Africa, "a significant proportion of road users have not had the financial means to pay for appropriate healthcare and rehabilitation themselves while waiting for the legal process to be finalised". ${ }^{234}$ For these reasons, the fault-based system of liability under the RAF Act has been described as "unreasonable, inequitable, unaffordable and unsustainable". ${ }^{235}$

In response to these difficulties, the RABS has been proposed. The preamble of the proposed legislation for motor vehicle accidents therefore states that "there is a need to expand and facilitate access to benefits by providing them on a no- fault basis". The suggested no-fault model under the RABS will potentially ease the "administrative load ... and speed up service delivery. Long delays in the settlement of claims will be eliminated by the fact that possible disputes over the fault requirement and which frequently required legal intervention will be removed and by the resulting streamlined administrative process". ${ }^{236}$

The proposal of a no-fault liability model under the proposed RABS provides an example of where the evidentiary difficulties in proving fault (in the form of negligence) has been used as a justifiable policy reason for legislative reform of the law of delict. ${ }^{237}$ It is envisaged that the proposed no-fault model will ease the administrative load regarding the process of statutory claims, increase the speed with which those claims are processed and prevent lengthy, costly legal disputes concerning the existence of negligence.

The introduction of a strict liability regime in the context of occupational injuries and diseases was similarly motivated by the desire to assist the victims of occupational injuries and diseases so that they are not required to prove fault. ${ }^{238}$

231 Department of Transport 2011: 13.

232 Idem at $1-7$.

233 Ibid.

234 Idem at 7.

235 Idem at 6.

236 Idem at 5.

237 See Law Society of South Africa v Minister for Transport 2011 (1) SA 400 (CC) par 45; Department of Transport 2011: 5 .

238 Markesinis \& Unberath 2002: 727-731. 


\section{BERNARD WESSELS}

Upon tabling COIDA to the extended public committee in parliament, the Minister of Manpower aptly remarked: ${ }^{239}$

Under common law an injured employee or the dependents of a deceased employee may get compensation from his employer if it can be proved that the injury or death was due to the negligence of the employer, but in a modern industrial set-up in which, for example, a number of employees jointly use sophisticated machinery, it may be virtually impossible for an injured employee to prove negligence.

With the introduction of COIDA and by doing away with proving fault within this context, the employee is therefore able to obtain compensation from a solvent entity much easier and quicker. ${ }^{240}$ It may therefore be argued that the compensation fund more effectively compensates victims than a delict/tort system that requires proof of fault. $^{241}$

Proving fault, especially negligence, is difficult and places a burden on the plaintiff that is often hard or impossible to discharge. ${ }^{242}$ This evidentiary difficulty has been a major policy consideration in favour of statutory intervention in the field of product liability, where the consumer is usually unable to analyse or scrutinise the products for safety. ${ }^{243}$ In Wagener, the SCA was requested to develop the rules of the common law of delict so that it was no longer required for victims of defective products to prove that the manufacturer had been culpable (in this case, negligent) in manufacturing the product in question. Although the court ultimately opted to leave the development of this branch of the law to the legislature, it took cognisance of the difficulty in proving fault: ${ }^{244}$

A plaintiff has no knowledge of, or access to the manufacturing process, either to determine its workings generally or, more particularly, to establish negligence in relation to the making of the item or substance which has apparently caused the injury complained of. And, contrary to what some writers suggest, it was urged that it is insufficient to overcome the problem that the fact of the injury, consequent upon use of the product as prescribed or directed, brings the maxim res ipsa loquitur into play and casts on the defendant a duty to lead evidence or risk having judgment given against it. The submission is that resort to the maxim is but a hypocritical ruse to justify (unwarranted) adherence to the fault requirement.

239 Proceedings of the Extended Public Committee 1994: col 12305.

240 For a German perspective on this point, see Markesinis \& Unberath 2002: 727.

241 See, also, Stapleton 1986: 12, who writes about English legislation that provides an occupational injuries scheme: "The principal advantage the scheme has over tort ... is that fault in an identifiable wrongdoer need not be shown, nor, in most cases, need the claimant affirmatively prove medical causation, as he or she can take advantage of presumptions to this effect."

242 Loubser \& Reid 2012: 4.

243 Ibid.

2442003 (4) SA 285 (SCA) par 10. 
A by-product of a strict liability regime in this context is the fact that it assists in promoting consumer safety and deterring the manufacturing of dangerous products. In the product liability context, the abolition of the fault requirement appears to perform the instrumental function of creating safety incentives. ${ }^{245}$ Imposing strict liability on manufacturers for harm caused by manufacturing defects encourages greater investment in product safety than does a regime of fault-based liability under which sellers may escape their appropriate share of responsibility. ${ }^{246}$ In its 1985 Directive, the European Union also emphasised the fact that the imposition of a strict liability regime relating to defective products is the "sole means of adequately solving the problem, peculiar to our age of increasing technicality, of a fair apportionment of the risks inherent in modern technological production". ${ }^{247}$

These considerations have prompted the South African legislature to shift the harm suffered by consumers due to defective products onto the risk creator who directly stands to benefit from the risk-taking. ${ }^{248}$ The introduction by the South African legislature of the strict liability regime for defective products under section 61(1) of the CPA practically assists consumers in protecting their legal interests in cases involving complex products and where it would otherwise have been difficult or impossible to attain expert evidence to prove the defendant's fault. ${ }^{249}$

In conclusion, it may be said that the argument against fault (especially in the form of negligence) has been successful in both South Africa and foreign jurisdictions in spurring legislative development of the law of delict/tort in a variety of contexts, notably harm resulting from defective consumer products, workplace-related injuries and diseases and motor vehicle accidents. ${ }^{250}$ It is submitted that the requirement to prove fault, especially negligence, in some instances may place a burden on victims of harm that is very difficult, or potentially impossible to satisfy, thereby potentially leaving them without compensation.

\section{The nature of the civil litigation process: Under-compensation and high transaction costs}

From a comparative perspective, the common law of tort has been criticised as being ineffective in its principal aim of compensating harm resulting from especially personal injury, disease and death. ${ }^{251}$ Dissatisfaction with the operation of the tort system received widespread academic attention during the 1960s and 1970s. ${ }^{252}$

245 Loubser \& Reid 2012: 5.

246 Ibid.

247 Ibid.

248 See, also, Stapleton 1986: 92.

249 Loubser \& Reid 2012: 4.

250 See, also, Sugarman 1987: 804-805.

251 Cane 2006: 461-499; Deakin, Johnston \& Markesinis 2013: 51-59.

252 See, in general, Ison 1967; Elliot \& Street 1968; Atiyah 1970. 


\section{BERNARD WESSELS}

During the same time, mass tort litigation drew public attention to the clumsy, timeconsuming and costly nature of obtaining compensation by instituting civil proceedings. ${ }^{253}$

The vigorous academic and public debates in the UK about the shortcomings of the tort system as a compensation mechanism was further buoyed by the enactment of the Accident Compensation Act in New Zealand in 1972..$^{254}$ The Act abolished the tort system insofar as the compensation for harm resulting from personal injuries is concerned, and replaced it with a general compensation scheme that provided compensation for harm resulting from all accidents and some diseases. ${ }^{255}$ It was argued that such a legislative development would, inter alia, alleviate the concerns relating to the high transaction costs of the civil litigation system. Within this framework, the UK government established the Royal Commission on Civil Liability and Compensation for Personal Injury to investigate the need for reform of the common law of tort (Pearson Report). ${ }^{256}$

The Pearson Report revealed that out of the total number of some 3 million persons estimated to have suffered from personal injury each year, only approximately 1,7 million received financial assistance from any source, with some of the victims receiving compensation from more than one source. ${ }^{257}$ Significantly, it was found that: 258

[Out of the] estimated 3 million persons suffering some injury in each year, only some 125,000 (approximately 7 per cent) received any compensation in the form of tort damages. However, the total value of the damages paid to this 7 per cent was almost half of the total value of the social security payments made to the 1.5 million recipients of those payments. When account is taken of the administrative costs of the differing compensation systems, the position is even more striking, because the tort system is much more expensive to administer $\ldots$ of the total cost of compensation paid (on average in each of the years 1971-1976) some $£ 1$ billion, the tort system accounted for no less than $£ 377$ million. Thus, 7 per cent of the accident victims accounted for perhaps 37 per cent of the total cost (payments plus administration) of the compensation paid out (making some allowance for the estimated administrative costs).

The Pearson Report indicated the high costs associated with the tort system which, in relation to other sources of compensation, seemed "less significant if its importance is assessed not in relation to accident victims alone, but in relation to the tentimes larger group of people who are disabled from all causes, these predominantly being illness and disease". ${ }^{259}$

253 Cane 2006: 459.

254 This Act has since been replaced by the Accident Compensation Act of 2001.

255 Cane 2006: 459.

256 The Pearson Report was published in 1978.

257 Cane 2013: 19-21.

258 Ibid (own emphasis)

259 Lewis 2013: 288. 
Although there are no up-to-date statistics to put alongside those provided in the Pearson Commission's report, it has been argued that "there is little reason to think that the basic picture is significantly different now". ${ }^{260}$ In addition, it has been stated that, although "[f]igures for South Africa are not known, they are likely to show similar trends". ${ }^{261}$

In the South African context, it may be argued that, similar to the position in England ${ }^{262}$ and elsewhere, ${ }^{263}$ civil litigation is expensive ${ }^{264}$ and only a limited number of plaintiffs can afford the accompanying legal transaction costs, ${ }^{265}$ thereby restricting the right of general access to justice. ${ }^{266}$ Legal costs and fees in South Africa are substantial, leading some to argue that "the major barrier to access to justice in South Africa remains the high cost of legal services" ${ }^{267}$ It is therefore unsurprising that in EFF $v$ Speaker of the National Assembly; DA v Speaker of the National Assembly, ${ }^{268}$ Mogoeng CJ recently emphasised the fact that "[1]itigation is prohibitively expensive and therefore not an easily exercisable constitutional option for an average citizen".

To illustrate, in 2005, the average South African household would have had to use a week's income to afford a one-hour consultation with an average attorney. ${ }^{269}$

260 Cane 2013: 19-21.

261 Loubser \& Midgley 2012: 9.

262 Lord Justice Jackson was appointed to carry out a fundamental review of the costs in civil litigation in England and Wales. He published his final report in 2010, in which he found that the costs relating to civil litigation (especially in respect of personal injuries) are excessive and has recommended substantial changes in this regard. See Jackson 2010: 14-18; Jackson 2011: 37-42. In their comparative study, analysing data from Australia, Austria, Belgium, Bulgaria, Canada, China, Czech Republic, Denmark, England and Wales, Estonia, Finland, France, Germany, Greece, Hong Kong, Hungary, Ireland, Italy, Japan, Latvia, Lithuania, the Netherlands, Norway, Poland, Portugal, Romania, Russia, Scotland, Singapore, Spain, Sweden, Switzerland, Taiwan and the USA, Hodges, Vogenauer \& Tulibacka 2009: 3-9 note that, generally speaking, litigation costs are expensive and time-consuming and encourages further reform so as to improve access to justice.

263 Hodges, Vogenauer \& Tulibacka 2009: 3-9. According to Sugarman 1987: 795, tort law is "an intolerably expensive and unfair system of compensating victims".

264 See Wallis 2011: 33-37; Klaaren 2014: 1-6.

265 In other words, costs relating to the investigation of claims and the overall litigious process. See Wallis 2011: 33-37; Klaaren 2014: 1-6. For a comparative perspective, see, also, Deakin, Johnston \& Markesinis 2013: 53; Hodges, Vogenauer \& Tulibacka 2009: 3-9. See, also, Sugarman 1987: 798: "The money available for compensation is paid into insurance companies as liability insurance premiums finds its way into the pockets of victims. The rest is ground up in lawyers' fees and the associated costs that litigation generates. The money also is consumed in the marketing, general overhead and claims administration costs of the insurers, as well as their profits in years when they make profits. Furthermore, there are public costs to the judicial system that the tort system imposes, both financial and through delay in the handling of other cases."

266 See SALRC 2004: 236; Wallis 2011: 33-37; Klaaren 2014: 1-6; Cane 2006: 461-499; Cane 1997: 231-237; Sugarman 1985: 73.

267 AfriMAP and the Open Society Foundation for South Africa 2005: 2, 108.

2682016 (5) BCLR 618 (CC) par 52.

269 Klaaren 2014: 2. 
More recently, in 2013, it was recorded that "clients with a monthly income of R600 ... are frequently charged fees in the region of $\mathrm{R} 1500 \ldots$ just for an initial consultation". ${ }^{270}$ In accordance with the Rules Board for Courts of Law Act 107 of 1985, a 15-minute consultation may cost anything between R144 and R235, while the cost of drafting one page of a legal document may be charged at R50. ${ }^{271}$ It also restricts access to justice for the poor, especially civil justice, which is largely not available from Legal Aid South Africa. ${ }^{272}$ These fees restrict access to justice across the board for the not-so-poor, for instance persons in a household earning over R6 000 a month and thus not qualifying for Legal Aid. ${ }^{273}$

There are additional factors that may contribute towards the high cost of instituting a civil claim in a South African court. There are approximately 26000 legal practitioners in South Africa, serving at least 53 million people. ${ }^{274}$ However, around 2500 of these practitioners are advocates who rarely have direct interaction with clients, especially poor ones. Furthermore, the vast majority of these practitioners are situated in the urban areas, with relatively few practising in small towns or rural areas, which means that "the cost and distance required to physically access lawyers makes pursuing litigation an overwhelmingly impractical option". ${ }^{275}$

Although the number of legal practitioners continues to grow, it has not led to greater competition, lower fees, more affordable legal assistance and greater access to justice. ${ }^{276}$ In addition, as noted above, the civil litigation process is timeconsuming, resulting in many plaintiffs electing not to institute their claims at all.277 As a result, taking into account the high cost and time-consuming nature of litigation in this regard, private insurance has assumed an increasingly important role, relieving victims of loss of their financial burden. ${ }^{278}$ However, considering the levels of poverty in South Africa, the vast majority of citizens are probably not in a position to afford insurance.

270 Dugard \& Drage 2013: 2.

271 See, also, Holness 2013: 129-130.

272 Klaaren 2014: 2

273 Ibid.

274 Law Society of South Africa 2015: 25, 49.

275 Dugard \& Drage 2013: 2.

276 Wallis 2011: 33-37.

277 Sugarman 1985: 558-622. See, also, Sugarman 1987: 796: "When someone now makes a tort claim, rather than obtaining swift justice, he often will wind up waiting years before his suit is resolved. Moreover, he frequently will come away from the experience far more frustrated than satisfied. A victim today rarely can expect to recover directly from the individual who injured him. Instead, he will recover from an insurance company or a large impersonal enterprise, such as a corporation or a government entity."

278 Cane 2006: 461-499; Deakin, Johnston \& Markesinis 2013: 51-59; Hedley 2013: 249. 
The concern over the costly and time-consuming nature of civil proceedings is not new to the South African legal landscape. In its Report on Compensation to Workmen in 1904, the Select Committee already took note of the problems raised by employees that the litigation process "has undoubtedly lengthened the time between the occurring of the accident and the receiving of the compensation" 279 and that the proposed Workmen's Compensation Act of 1905 had to provide compensation "to poor men quickly, and as cheaply as possible". ${ }^{280}$ The same sentiment was echoed when the legislature decided to introduce a no-fault based compensatory system for occupational injuries and diseases via COIDA: "In exchange for [forfeiting his common-law claim against his employer, the employee] gets an immediate remedy in the form of a statutory right to compensation without having to prove negligence on the part of the employer." 281

In its judgement relating to the constitutionality of the abolition of the motor vehicle accident victim's common-law claim against a wrongdoer in Law Society of South Africa v Minister for Transport, ${ }^{282}$ the Constitutional Court commented on the nature of the civil litigation process:

The right of recourse under the common law proved to be of limited avail. The system of recovery was individualistic, slow, expensive and often led to uncertain outcomes. In many instances, successful claimants were unable to receive compensation from wrongdoers who had no means to make good their debts. On the other hand, it exposed drivers of motor vehicles to grave financial risk.

The legislature has aimed to remedy this concern by, among other things, introducing a no-fault basis for compensation of harm arising from motor vehicle accidents. Furthermore, as the preamble to the proposed RABS indicates, the legislature has identified the "need to simplify claims procedures, reduce disputes and create certainty by providing defined and structured benefits ... and there is a need to establish administrative procedures for the expeditious resolution of disputes that may arise and to alleviate the burden on the courts".

Lastly, the time-consuming nature and high transaction costs characteristic of the civil litigation process was also taken into account when drafting the provisions of the CPA that relate to its regulatory framework and access of justice. ${ }^{283}$ With the introduction of the CPA, the legislature has changed not only the substantive law relating to defective consumer products, but it also effected changes to the administration of justice insofar as the adjudication of consumer rights and disputes involving consumers and business are concerned. For example, under the new regulatory framework, the National Consumer Tribunal (NCT) and the

279 Select Committee 1904: 12.

280 Idem at 2.

281 Proceedings of the Extended Public Committee 1994: col 12306.

2822011 (1) SA 400 (CC) par 17.

283 Van Eeden 2013: 93-105, 387-447. 
National Consumer Commission (NCC) have important roles. ${ }^{284}$ While the NCT is an adjudicative body, empowered to adjudicate on applications and allegations of prohibited practice, ${ }^{285}$ the NCC is primarily an investigative body that aims to enforce the provisions by the Consumer Protection Act (CPA) ${ }^{286}$ The establishment of these bodies, as well as consumer courts, may be regarded as a response to the need for a cheaper, speedier, more flexible and informal regulatory system. ${ }^{287}$

It is argued that the nature of the civil litigation process, notably its potential under-compensation of harm and the accompanying high transaction costs, has played a significant role in justifying the legislative reform of the law of delict in the areas where the need for this type of reform is most pressing and where the effect of reform can be most widespread and cost effective.

\section{The ability of the legislature to regulate liability more comprehensively than the judiciary}

Another consideration that have justified the statutory development of the law of delict is the ability of the legislature to regulate liability more comprehensively than the judiciary. In Wagener, the Supreme Court of Appeal took account of the debate surrounding the potential introduction of a strict liability regime for harm caused by defective consumer products. The court noted that product liability reform in foreign jurisdictions had largely been achieved through legislation and ultimately concluded that South Africa should adopt the same route: "If strict liability is to be imposed, it is the Legislature that must do it." ${ }^{288}$ In its judgement, it held that the legislature was better equipped to investigate the variety of questions that would have to be answered prior to introducing a strict liability regime in the context of defective products: ${ }^{289}$

1. What products should be included ... when it comes to determining the extent of the liability? 2. Is a manufacturer to include $X$, the maker of a component that is part of the whole article manufactured by $\mathrm{Y}$; and which is liable if the component is defective? 3. Does

284 See s 69 of the CPA.

285 The NCT can make the following orders: grant interim relief, declare conduct to be prohibited, issue an interdict for prohibited conduct, impose administrative fines, confirm consent orders, condone non-compliance with its rules and procedures, confirm an order against an unregistered person to cease engaging in certain activities, cancel or suspend a registrant's registration, require payment to the consumer of any excess amount charged, together with interest at the rate set out in the agreement and any order required to give effect to a right set out in the Act.

286 It seeks to initiate and receive complaints, refer complaints for dispute resolution, investigate and evaluate alleged prohibited conduct and offences, conduct interrogations, issue and enforce compliant notices and make referrals to the NCC. In practice, however, many of these functions are now fulfilled by the industry ombuds.

287 Van Eeden 2013: 98-99.

2882003 (4) SA 285 (SCA) pars 30-36.

289 Ibid. 


\title{
LEGAL AND PUBLIC POLICY CONSIDERATIONS
}

\begin{abstract}
defect mean defect in the making process only or, in the case of a designed article, also a defect of design? Should it include the failure, adequately or at all, to warn of possible harmful results? 4. Should the liability be confined to products intended for marketing without inspection or extend even to cases where the manufacturer does, or is legally obliged to, exercise strict quality control? 5. What relevance should the packaging have-should liability, for example, be limited to cases where the packaging precludes intermediate examination or extend to cases where the manufacturer stipulates that a right such as a guarantee would be forfeited if intermediate examination were made? 6. Is a product defective if used innocuously on its own, but which causes damage when used in combination with another's product? 7. What defences should be available? ... 8. Should the damages recoverable be exactly the same as in the case of the Aquilian claim or should they be limited, as in some jurisdictions, by excluding pure economic loss or by limiting them to personal injury?
\end{abstract}

The court held that single instances of litigation could not provide the opportunity for conducting the thorough investigation, analysis and determination that was necessary to produce a cohesive and effective structure by which to impose strict liability. ${ }^{290}$ The court's recommendation was ultimately heeded and the legislature, with the benefit of more empirical data, time and product liability expertise, enacted the CPA. ${ }^{291}$

In addition to the CPA, COIDA and the RAF Act are further examples of where the legislature reformed major areas of the law of delict. The enactment of these statutes enabled major legislative reform of the law of delict, as opposed to incremental judicial development of an element of delictual liability. It is submitted that, whenever large-scale development of a specific area within the law of delict may be required by specific policy-based considerations as those discussed in parts 2.1-2.3 above, it appears more appropriate to follow the legislative route. Indeed, this much was also recognised by the Constitutional Court, which stated as follows: ${ }^{292}$

In exercising their powers to develop the common law, Judges should be mindful of the fact that the major engine for law reform should be the Legislature and not the Judiciary. In this regard it is worth repeating the following dictum ... "Judges can and should adapt the common law to reflect the changing social, moral and economic fabric of the country. Judges should not be quick to perpetuate rules whose social foundation has long since disappeared. Nonetheless there are significant constraints on the power of the Judiciary to change the law. ... In a constitutional democracy such as ours it is the Legislature and not the courts which has the major responsibility for law reform. ... The Judiciary should confine itself to those incremental changes which are necessary to keep the common law in step with the dynamic and evolving fabric of our society".

290 Ibid.

291 From a comparative perspective, see, also, Cambridge Water Co v Eastern Counties Leather plc [1994] 2 AC 264 at 305: "I incline to the opinion that, as a general rule, it is more appropriate for strict liability in respect of operations of high risk to be imposed by Parliament, than by the courts."

292 Carmichele v Minister of Safety and Security 2001 (4) SA 938 (CC) par 36 (references omitted). 


\section{The need to avoid arbitrary outcomes}

In Fourway Haulage SA (Pty) Ltd v SA National Roads Agency Ltd, ${ }^{293}$ Brand JA reaffirmed the fact that any "legal system in which the outcome of litigation cannot be predicted with some measure of certainty would fail in its purpose .... We therefore strive for certainty". This part prompts us to consider how the need to avoid arbitrary outcomes in litigation, and thus to ensure legal certainty, could motivate law makers to develop the law of delict (or in common-law parlance, tort law).

Scholars have argued that the tort system is essentially a "lottery" 294 and that it "produces arbitrary outcomes". ${ }^{295}$ Sugarman summarises this argument as follows:

[W] hat count considerably are: the talents of the lawyer one happens to have; the tenacity of the defendant (or insurance adjuster) one happens to be up against; whether the defendant happens to be a motorist, a company, or a governmental entity; how attractive (but not too attractive) and how well spoken (but perhaps not too well spoken) the claimant happens to be; what race the claimant is; what state and community the victim lives in; how well one is able to hold out for a larger settlement; the whim of the jury if the case gets that far; and whether one is lucky enough to have available the right sort of witnesses or other evidence of the injury and the defendant's wrongdoing. In short, our current tort system is not a system of justice; it is a lottery.

From this perspective, the imposition of tortious (or in our case, delictual) liability and the payment of damages are impacted on by considerations unrelated to what the parties deserve. ${ }^{296}$ The outcome of litigation may be substantially determined by contingent factors, including the availability of evidence, the quality of counsel, the limits of insurance coverage, the financing of litigation, the whims of judges (and, in common-law jurisdictions, juries), and many other factors that are not conducive to the consistent and principled application of law. ${ }^{297}$

The argument that the tort system is unfair and unpredictable has been advanced to justify reform proposals in some way or the other. For example, in New Zealand, these arguments eventually won the day and secured the development of the law relating to the compensation of personal injuries arising from accidents. In its 1967 report, the Royal Commission of Inquiry into Compensation for Personal Injury in New Zealand asserted that "[t]he toll of personal injury is one of the disastrous incidents of social progress". ${ }^{298}$ The Commission identified a number of weaknesses with the mechanisms available for dealing with personal injury, including particular

2932009 (2) SA 150 (SCA) pars 16-17.

294 Sugarman 1987: 796.

295 Franklin 1967: 774: "[T]he fault system is little more than an immoral lottery for both plaintiffs and defendants." See, also, Atiyah 1996: 143.

296 Lytton, Rabin \& Schuck 2010: 269.

297 Idem at 268-269.

298 New Zealand Law Commission 2008: 3. 
problems with tort law. One of the problems with tort law in cases of personal injury included "the difficulty of establishing liability for loss and of attaching a monetary value to that loss, resulting in the law being seen as, at best, uncertain and in some cases arbitrary and capricious". ${ }^{299}$ Eventually, the legislature introduced the Accident Compensation Act in New Zealand in 1972, thereby abolishing the tort claim for harm arising from accidents.

Arguably, the statutory development of the law of delict by the CPA, COIDA and the RAF Act has been motivated by similar considerations. For instance, with regard to the introduction of a strict liability regime for defective consumer products, the Supreme Court of Appeal implied that such a development should be driven by the legislature, because it could provide a more principled, logical and fair solution for the particular problem. ${ }^{300}$

Furthermore, in line with the arguments raised in foreign jurisdictions, the statutory development of COIDA and the RAF Act (and the proposed RABS) appears to be motivated by the general consideration to ensure that the outcome of litigation is not influenced by the contingent factors mentioned above. After all, the likelihood of a victim receiving compensation under those statutes is not dependent on the quality of counsel, the limits of insurance coverage, the financing of litigation, or the whims of a particular judge.

\section{Conclusion}

The legal position surrounding crime victim compensation may be described as unsatisfactory. ${ }^{301}$ As indicated in the introduction to this contribution, the current compensatory regime is characterised by various theoretical and practical problems. From a practical and financial perspective, the continued state delictual liability for harm arising from crime means that more and more taxpayer funds, which were earmarked to be used in crime prevention campaigns, are used to satisfy civil claims. If this trend continues, less money will be available for combating crime, resulting in more litigation against the state. Ultimately, this cycle of ever-expanding state delictual liability threatens the state's ability to combat crime and to comply with its constitutional obligations to protect its citizens. From a theoretical point of view, the expansion of state delictual liability is problematic, not the least because it may produce uncertainty and arbitrary outcomes in future litigation. ${ }^{302}$

299 Ibid.

300 Wagener v Pharmacare Ltd; Cuttings v Pharmacare Ltd 2003 (4) SA 285 (SCA) pars 28-31.

301 See, generally, Wessels 2018: 31-127.

302 A full and thorough analysis of the theoretical concerns associated with this development falls well outside the scope of this contribution. However, see the comments made in part 1 supra, as well as the sources cited in the footnotes there, for a detailed discussion of these problems. 
Against this background, it may be considered whether there is an alternative method to provide compensation for crime victims. One particular alternative that has been adopted in a variety of foreign jurisdictions is the establishment of a statutory compensation fund for crime victims. Should such an alternative be adopted by the South African legislature, it will amount to the statutory development of the law of delict insofar as the compensation of a specific group of victims is concerned. However, for the reasons mentioned in the introduction to this contribution, the adoption of such an alternative and subsequent development of the common law requires a justifiable theoretical framework.

To establish such a framework, this contribution has examined the historical backgrounds of important statutory developments within the law of delict. This investigation has identified legal and public policy considerations that have justified the earlier instances of legislative reform. It is proposed that these considerations may also aid in providing the necessary theoretical framework on the basis of which the law of delict may justifiably be developed in the future, at least insofar as the issue of compensation is concerned.

The first consideration that was highlighted was the role played by the increased risk of harm and the associated risk of no recovery of compensation. This consideration was paramount in developing the law of delict's compensatory response to victims of motor vehicle accidents, defective consumer products and occupational injuries and diseases. Although there is an undeniable utility associated with motor vehicle transportation, enlarged labour forces and a growing manufacturing sector, these benefits were accompanied by a substantial increase in the risk of harm arising from those sectors. This required the South African legislature to produce a solution in which these activities were permitted, but only on the condition that the most appropriate enterprise was saddled with the cost of the risks it produced. Ultimately, it decided that, in order to more effectively secure the compensation of a victim's harm, the compensatory mechanism would have to be reconfigured within a statutory context.

The decision to do so was informed also by the significant desire to promote social security. Prior to the advent of the Constitution, the achievement of greater social security was already identified as a clearly pronounced goal that justified the statutory interference with the common law of delict. The legislature's desire to provide a variety of accident victims with remedies that gave quicker and more costeffective access to compensation and to distribute the risk of certain risk-related activities throughout society may therefore be regarded as an important consideration that have justified the development of the law of delict in a variety of contexts.

With the enactment of the Constitution, and the entrenchment of the right to social security as a fundamental human right, the legislature has openly committed itself towards the notion of spreading risk to promote social inclusion and social solidarity. The statutory establishment of compensation funds in respect of motor vehicle accidents and occupational injuries and diseases - arguably two spheres in 
which most individuals are most frequently exposed to the risk of harm - achieves these goals.

Furthermore, the evidentiary difficulties involved in satisfying the common-law requirement of fault, specifically in the form of negligence, has been criticised as imposing a significant stumbling block on the pathway to obtaining compensation. Otherwise deserving victims of harm have been struggling to satisfy this requirement and, where the matter has been argued in court, a clear preference has been given for the reform to be driven by a legislative process. Statutory reform provides an advantage that single instances of litigation do not: it enables all the relevant stakeholders to partake in the thorough processes of investigation, analysis and determination that are required to produce a cohesive and effective structure for the development of the law of delict.

By removing fault as a requirement for obtaining compensation, victims of workplace injuries and diseases and defective consumers now have a greater theoretical chance in succeeding with finding redress for the harm they have suffered. Similarly, as indicated above, the proposed RABS will provide comparable opportunities. In addition to achieving greater compensation levels than the faultbased system of delictual liability, the statutory development of the law of delict have clearly been informed by considerations of time and money.

Other general considerations that have been used to justify the statutory development of the law of delict has also been considered justified where it has enabled a more time-efficient and cost-effective route to compensation and where it has succeeded in providing a principled, consistent approach to compensation.

It is proposed that the legal and public policy considerations identified in this contribution aid in providing a justifiable theoretical framework for the statutory development of the law of delict insofar as compensation of victims is generally concerned. However, by itself it does not yet justify why crime victims should be singled out as a specific category of victims that may come into consideration for statutory compensation (as opposed to any other category of victim). Indeed, as alluded to in the introduction of this contribution, where statutory compensation funds for crime victims have been enacted, some concern has been expressed about the singling out of this specific group of victims for preferential treatment.

Attention must now be given to the question whether the specific development of the law of delict through the enactment of a statutory compensation fund for crime victims can be justified on the basis of the considerations identified in this contribution.

\section{Bibliography}

AfriMAP and the Open Society Foundation for South Africa (2005) South Africa: Justice Sector and the Rule of Law

American Law Institute (1965) Second Restatement of Torts vol 2 (St Paul, Minn) 


\section{BERNARD WESSELS}

Atiyah, P (1970) Accidents, Compensation and the Law 1 ed (London)

Atiyah, P (1996) The Damages Lottery (Oxford)

Bartrip, P (2010a) "No-fault compensation on the roads in twentieth century Britain" Cambridge LJ 69(2): 263-286

Bartrip, P (2010b) "Pedestrians, motorists, and no-fault compensation for road accidents in 1930s Britain” J of Legal History 31: 45-60

Brodie, D (2010) Enterprise Liability and the Common Law (Cambridge)

Budlender, D (1984) “The Workmen's Compensation Act” South African Labour Bulletin 9(4): $22-41$

Cameron, BJ (1963) "Compensation for victims of crime, the New Zealand experiment" J of Public Law 12: 367-375

Canadian Resource Center for Victims of Crime $(s d)$ "Financial assistance" available at https:// crcvc.ca/for-victims/financial-assistance/ (accessed 28 Jun 2017)

Cane, P (1997) The Anatomy of Tort Law (Oxford)

Cane, P (2006) Atiyah's Accidents, Compensation and the Law 7 ed (Cambridge)

Cane, P (2013) Atiyah's Accidents, Compensation and the Law 8 ed (Cambridge)

Coleman, J (1982) “Corrective justice and wrongful gain” J of Legal Studies 11: 421-440

Coleman, J (1987) "Property, wrongfulness, and the duty to compensate" Chicago-Kent LR 63: $451-470$

Coleman, J (1992a) "The mixed conception of corrective justice" Iowa LR 77: 427-444

Coleman, J (1992b) Risks and Wrongs (Cambridge)

Coleman, J (1992c) "Tort law and the demands of corrective justice" Indiana LR 67: 349-379

Coleman, J (1995a) "The practice of corrective justice" in DG Owen (ed) Philosophical Foundations of Tort Law (Oxford): 53-73

Coleman, J (1995b) "Doing away with tort law" Loyola of Los Angeles LR 41: 1148-1170

Cooper, W (1996) Delictual Liability in Motor Law 2 ed (Cape Town)

Deak, F (1936) "Compulsory liability insurance under the British Road Traffic Acts of 1930 and 1934" Law and Contemporary Problems 3(4): 565-570

Deakin, S, A Johnston \& B Markesinis (2013) Markesinis and Deakin's Tort Law (Oxford)

Deakin, S (2013) “Tort law and workmen's compensation legislation: Complementary or competing models?" in TT Arvind \& J Steele (eds) Tort Law and the Legislature (Oxford): 253-267

Dendy, M (2014) “Agency and representation” in WA Joubert \& JA Faris (eds) LAWSA 13 ed (Durban): pars 125-183

Department of Transport (2011) Policy Paper for the RABS

Dereymaeker, G (2015) "Making sense of the numbers: Civil claims against the SAPS" South African Crime Quarterly 54: 29-41

Dugard, J \& K Drage (2013) “To whom do the people take their issues?" Justice and Development Working Paper Series 21: 1-41

Elliot, DW \& H Street (1968) Road Accidents (London) 


\section{LEGAL AND PUBLIC POLICY CONSIDERATIONS}

Fagan, A (2012) “The right to personal security" in E Reid \& D Visser (eds) Private Law and

Human Rights: Bringing Rights Home in Scotland and South Africa (Cape Town): 130-155

Fairgrieve, D (ed) (2005) Product Liability in Comparative Perspective (Cambridge)

Fletcher, GP (1972) "Fairness and utility in tort theory" Harvard LR 85: 537-573

Franklin, MA (1967) "Replacing the negligence lottery: Compensation and selective reimbursement" Virginia LR 53: 774-814

Fry, M (1959) "Justice for victims" J of Public Law 8: 191-194

Goodey, J (2003) Compensating Victims of Violent Crime in the European Union (Vienna)

Greer, D (ed) (1996) Compensating Crime Victims: A European Survey (Freiburg)

Grote, R (2008) "Product liability under German and European law" in M Wendler, B Buecker \& B Tremml (eds) Key Aspects of German Business Law: A Practical Manual (Heidelberg): $107-116$

Hansard Debatte van die Volksraad (1942) vol 43 cols 1255-1259

Hedley, S (2013) "Tort and personal injuries, 1850 to the present" in TT Arvind \& J Steele (eds) Tort Law and the Legislature (Oxford): 235-251

Hodges, C, S Vogenauer \& M Tulibacka (2009) "Costs and funding in civil litigation: A comparative study" University of Oxford Legal Research Paper Series 55: 1-119

Holness, D (2013) "Recent developments in the provision of pro bono legal services by attorneys in South Africa" PER 16(4): 129-164

Hutchison, D \& CJ Pretorius (eds) (2012) The Law of Contract in South Africa 2 ed (Cape Town)

International Labour Office (2013) Strengthening the Role of Employment Injury Schemes to Help Prevent Occupational Accidents and Diseases (Geneva)

Ison, T (1967) The Forensic Lottery (London)

Jackson, RM (2010) Report: Review of Civil Litigation Costs available at https://www.judiciary. uk/wp-content/uploads/JCO/Documents/Reports/jackson-final-report-140110.pdf (accessed 13 Dec 2019)

Jackson, RM (2011) "Reform of the costs regime" Advocate 24(2): 37-42

Howells, G (2006) "Product liability" in J Smits (ed) Elgar Encyclopedia of Comparative Law (Cheltenham): 578-587

Klaaren, J (2014) "The cost of justice" Briefing Paper for Public Positions Theme Event, 24 March 2014, WiSER, History Workshop \& Wits Political Studies Department: 1-7

Kleeberg, JM (2003) "From strict liability to workers' compensation: The Prussian Railroad Law, the German Liability Act, and the introduction of Bismarck's accident insurance in Germany, 1838-1884" J for International Law and Politics (36): 53-132

Klopper, HB (2000) Law of Third Party Compensation (Durban)

Law Society of South Africa (2015) Statistics for Legal Education and Development (LEAD) and the Legal Profession (2014/2015)

Lewis, R (2012) “Employer's liability and workers' compensation: England and Wales” in K Oliphant \& G Wagner (eds) Employer's Liability and Workers' Compensation (Berlin): 137202 


\section{BERNARD WESSELS}

Lewis, R (2013) "Recovery of state benefits from tort damages: Legislating for and against the welfare state" in TT Arvind \& J Steele (eds) Tort Law and the Legislature (Oxford): 288-302

Loubser, MM (1993) Inleiding tot MMF-Wetgewing (Pretoria)

Loubser, MM \& E Reid (2012) Product Liability (Cape Town)

Loubser, MM \& JR Midgley (eds) (2017) Law of Delict in South Africa (Cape Town)

Lytton, TD, RL Rabin \& PH Schuck (2010) "Tort as litigation lottery: A misconceived lottery" Boston College Review 52: 267-288

Macintosh, JC (1926) Negligence in Delict (Cape Town)

Markesinis, B \& H Unberath (2002) The German Law of Torts 4 ed (Oxford)

McGillis, D \& P Smith (1983) Compensating Victims of Crime: An Analysis of American Programs (US Department of Justice)

McKerron, RG (1956) The Apportionment of Damages Act (Cape Town)

McKerron, RG (1971) The Law of Delict: A Treatise on the Principles of Liability for Civil Wrongs in the Law of South Africa (Cape Town)

Merkin, R \& S Dzibion (2013) "Tort law and compulsory insurance" in TT Arvind \& J Steele (eds) Tort Law and the Legislature: Common Law, Statute and the Dynamics of Legal Change (Oxford): 303-325

Miers, D (2014) "Offender and state compensation for victims of crime: Two decades of development and change" International Review of Victimology 20(1): 145-168

Midgley, JR \& JC van der Walt (2016) Principles of Delict 4 ed (Durban)

Myburgh, P, N Smit \& D van der Nest (2000) "Social security aspects of accident compensation: COIDA and RAF as examples" Law, Democracy and Development 4(1): 43-58

National Center for Victims of Crime (2004) Repairing the Harm (Washington)

Neethling, J \& JM Potgieter (2015) Neethling-Potgieter-Visser The Law of Delict 7 ed (Durban)

New Zealand Law Commission (2008) Compensating Crime Victims Issue Paper 11 (Oct) available at https://www.lawcom.govt.nz/sites/default/files/projectAvailableFormats/NZLC\%20IP11. pdf (accessed 13 Dec 2019)

Olivier, MP (2007a) "Social security: Core elements" in WA Joubert \& JA Faris (eds) LAWSA 13(3) 2 ed (Durban): pars 1-304

Olivier, MP (2007b) "Social security: Framework" in WAJoubert and JA Faris (eds) LAWSA 13(2) 2 ed (Durban): pars 1-196

Olivier, MP, JF Khoza, L Jansen van Rensburg \& E Klinck (2003) “Constitutional issues” in MP Oliver, N Smit \& E Kalula (eds) Social Security: A Legal Analysis (Durban): 49-119

Olivier, MP, MC Okpaluba, N Smit \& M Thompson (eds) (1999) Social Security Law: General Principles (Durban)

Proceedings of the Extended Public Committee (1994) Debates of Parliament 1993-1994 col 12305

Reimann, M (2003) "Liability for defective products at the beginning of the twenty-first century: Emergency of a worldwide standard?" American J of Comparative Law 51(4): 751-838

Reimann, M (2015) "Product liability" in M Bussani \& AJ Sebok (eds) Comparative Tort Law: Global Perspectives (Cheltenham): 250-279 


\section{LEGAL AND PUBLIC POLICY CONSIDERATIONS}

Road Accident Fund Commission (2002) Report of the Road Accident Fund Commission (Pretoria)

Royal Commission on Civil Liability and Compensation for Personal Injury (1978) Pearson Report

Scott, RE (1967) "Compensation for victims of violent crimes: An analysis" William \& Mary LR 8(2): 277-293

Select Committee of the House of Assembly (1904) Report of the Select Committee on Compensation to Workmen

South African Law Reform Commission (2004) A Compensation Fund for Victims of Crime Report Project 82

South African Law Reform Commission (2017) Medico-legal Claims Project 141

South African Institute for Race Relations (2016) Race Relations in South Africa: Reasons for Hope

Spencer, JR (1983) "Rylands \& Fletcher: A chapter of accidents in the history of law and motoring" Cambridge LJ 42(1): 65-84

Stapleton, J (1986) Disease and the Compensation Debate (Oxford)

Stapleton, J (1994) Product Liability (Cambridge)

Stein, MA (2008) "Victorian tort liability for workplace injuries" University of Illinois LR 3: 933-984

Sugarman, S (1985) "Doing away with tort law" California LR 73: 555-664

Sugarman, S (1987) "Serious tort law reform” San Diego LR 24: 795-849

Suzman, A, G Gordes \& MW Hodes (1982) The Law of Compulsory Motor Vehicle Insurance in South Africa 3 ed (Cape Town)

Taschner, HC (2005) "Product liability: Basic problems in a comparative law context" in D Fairgrieve (ed) Product Liability in Comparative Perspective (Cambridge): 155-167

Todd, S (2011) "Forty years of accident compensation in New Zealand" Thomas M Cooley LR 28(2): 189-219

United States Agency International Development (2008) Worker's Compensation in the Republic of South Africa

Van der Merwe, NJ \& PJJ Olivier (1976) Die Onregmatige Daad in die Suid-Afrikaanse Reg 3 ed (Pretoria)

Van den Heever, FP (1944) Aquilian Damages in the South African Law (Cape Town)

Van der Nest, D (2003) "Motor vehicle accidents" in MP Olivier, N Smit \& ER Kalula (eds) Social Security: A Legal Analysis (Durban): 49-149

Van Eeden, E (2013) Consumer Protection Law in South Africa (Durban)

Van Gerven, W, P Larouche \& Lever J (eds) (2000) Cases, Materials and Text on National, Supranational and International Tort Law (Oxford)

Van Rensburg, ADJ, JG Lotz \& T van Rhijn "Contract” in WA Joubert \& JA Faris (eds) (2014) LAWSA 93 ed (Durban): pars 1-433

Von Bonde, JC (2007) Redress for Victims of Crime in South Africa: A Comparison with Selected Commonwealth Jurisdictions (LLD thesis, Nelson Mandela Metropolitan University)

Wallis, M (2011) "Reform of the costs regime - A South African perspective" Advocate 24(2): $33-37$ 


\section{BERNARD WESSELS}

Weinrib, E (1995) The Idea of Private Law (Oxford)

Weinrib, E (2002) "Corrective justice in a nutshell" The University of Toronto LJ 52: 349-356

Wessels, AB (2018) Developing the South African Law of Delict: The Creation of a Statutory Compensation Fund for Crime Victims (LLD thesis, Stellenbosch University)

Wessels, AB (2019) "The expansion of the state's liability for harm arising from medical malpractice: Underlying reasons, deleterious consequences and potential reform" J of South African Law 1: 1-25

White Paper (1964) "Compensation of victims of crimes of violence" (cmnd 2323)

\section{Case law}

\section{South Africa}

AA Mutual Insurance Association Ltd v Biddulph 1976 (1) SA 725 (AD)

Absa Bank Ltd v Bond Equipment (Pretoria) (Pty) Ltd 2001 (1) SA 372 (SCA)

Aetna Insurance Co v Minister of Justice 1960 (3) SA 273 (A)

Carmichele v Minister of Safety and Security 2001 (1) SA 489 (SCA)

Carmichele v Minister of Safety and Security (Centre for Applied Legal Studies Intervening) 2001 (4) SA $938(\mathrm{CC})$

Commercial Union Assurance Company of South Africa Ltd v Clarke 1972 (3) SA 508 (AD)

EFF v Speaker of the National Assembly; DA v Speaker of the National Assembly 2016 (5) BCLR 618 (CC)

Eskom Holdings Ltd v Hendricks 2005 (5) SA 503 (SCA)

Fourway Haulage SA (Pty) Ltd v SA National Roads Agency Ltd 2009 (2) SA 150 (SCA)

Hv Fetal Assessment Centre 2015 (2) SA 193 (CC)

Healy v Compensation Commissioner 2010 (2) SA 470 (E)

Jacobs $v$ Transnet Ltd t/a Metrorail 2015 (1) SA 139 (SCA)

Jooste v Supermarket Trading (Pty) Ltd 1999 (2) SA 1 (CC)

Kruger v Coetzee 1966 (2) SA 428 (A)

Law Society of South Africa v Minister for Transport 2011 (1) SA 400 (CC)

Le Roux v Dey; Freedom of Expression Institute Amici Curiae 2011 (3) SA 274 (CC)

Loureiro v Imvula Quality Protection (Pty) Ltd [2014] ZACC 4

Mankayi v Anglogold Ashanti Ltd 2010 (5) SA 137 (SCA)

Mankayi v Anglogold Ashanti Ltd 2011 (3) SA 237 (CC)

MEC for Education, Western Cape Province v Strauss 2008 (2) SA 366 (SCA)

MEC for Health $v$ DN 2015 (1) SA 182 (SCA)

Molefe v Compensation Commissioner 365 [2007] ZAGPHC

Oppelt v Department of Health, Western Cape 2016 (1) SA 325 (CC)

Op't Hof v SA Fire \& Accident Insurance Co Ltd 1949 (4) SA 741 (W) 


\section{LEGAL AND PUBLIC POLICY CONSIDERATIONS}

Pithey $v$ Road Accident Fund 2014 (4) SA 112 (SCA)

$R$ van Canquan 1956 (3) SA 355 (E)

Rose's Car Hire (Pty) Ltd v Grant 1948 (2) SA 466 (A)

Sanan v Eskom Holdings Ltd 2010 (6) SA 638 (GSJ)

Sea Harvest Corporation (Pty) Ltd v Duncan Dock Cold Storage (Pty) Ltd 2000 (1) SA 827 (SCA)

Thomas $v$ Minister of Defence and Military Veterans 2015 (1) 253 (SCA)

Victoria Falls Power Co Ltd v Lloyd NO 1908 TS 1164

Wagener v Pharmacare Ltd and Cuttings v Pharmacare Ltd 2003 (4) SA 285 (SCA)

Waring \& Gillow v Sherborne 1904 TS 340

Webster v Santam Insurance Co Ltd 1977 (2) SA 874 (AD)

Workmen's Compensation Commissioner v Norwich Union Fire Insurance Society Ltd 1953 (2) SA $546(\mathrm{AD})$

\section{Germany}

BGH VIZR 36/55 'Der Betrieb’ 1956

\section{United Kingdom}

Cambridge Water Co v Eastern Counties Leather plc [1994] 2 AC 264

Donoghue v Stevenson [1932] AC 562

Rylands $v$ Fletcher [1868] UKHL 1

Wing v London General Omnibus Company [1909] 2 KB 652

\section{United States of America}

Escola v Coca-Cola Bottling Co of Fresno 24 Cal 2d 453, 150 P 2d 436 (1944)

Greenman v Yuba Power Products 59 Cal 2d 57 (1963)

Henningsen v Bloomfield Motors Inc 32 NJ 358, 161 A 2d 6 (1960)

\section{Legislation}

\section{South Africa}

Apportionment of Damages Act 34 of 1956

Compensation for Occupational Injuries and Diseases Act 130 of 1993

Constitution of the Republic of South Africa, 1996

Consumer Protection Act 68 of 2008

Criminal Law (Sexual Offences and Related Matters) Amendment Act 32 of 2007

Criminal Procedure Act 51 of 1977 


\section{BERNARD WESSELS}

Defence Act 44 of 1957

Domestic Violence Act 116 of 1998

Employer's Liability Act 35 of 1886 (Cape)

Miners' Phthisis Act 19 of 1912

Miners' Phthisis Act 44of 1916

Miners' Phthisis Acts Consolidation Act 35 of 1925

Miners' Phthisis Allowances Act 34 of 1911

Miners' Phthisis Amendment Act 29 of 1914

Motor Vehicle Accident Act 84 of 1986

Motor Vehicle Insurance Act 29 of 1942

Multilateral Motor Vehicle Accidents Fund Act 93 of 1989

Occupational Health and Safety Act 85 of 1993

Occupational Diseases in Mines and Works Act 78 of 1973

Pneumoconiosis Act 57 of 1956

Pneumoconiosis Compensation Act 64 of 1962

Prevention of Organised Crime Act 121 of 1998

Road Accident Fund Act 56 of 1996

Road Accident Amendment Act 15 of 2005

Rules Board for Courts of Law Act 107 of 1985

Schools Act 84 of 1996

Silicosis Act 47 of 1946

South African Police Service Act 68 of 1995

South African Transport Services Act 9 of 1989

State Liability Act 20 of 1957

Workmen's Compensation Act 40 of 1905 (Cape of Good Hope)

Workmen's Compensation Act 36 of 1907 (Transvaal)

Workmen's Compensation Act 25 of 1914

Workmen's Compensation Act 59 of 1934

Workmen's Compensation Act 30 of 1941

Workmen's Compensation (Industrial Diseases) Act 13 of 1917

\section{New Zealand}

Accident Compensation Act of 1972

Accident Compensation Act of 2001

Criminal Injuries Compensation Act of 1963

Injury, Prevention, Rehabilitation and Compensation Act of 2001

Sentencing Act of 2002 


\section{LEGAL AND PUBLIC POLICY CONSIDERATIONS}

\section{United Kingdom}

Consumer Protection Act, 1987 (c 43)

Civil Partnership Act, 2004 (c 33)

Criminal Injuries Compensation Act, 1995 (c 53)

Fatal Accidents Act, 1976 (c 30)

Road Traffic Act, 1930 (c 43)

Road Traffic Act, 1988 (c 52)

Sale of Goods Act, 1979 (c 54)

\section{Germany}

Products Liability Act, 1989 